\title{
Megalobulimus dryades, a new species from the Atlantic Forest in southeastern Brazil, and redescription of Megalobulimus gummatus (Gastropoda: Strophocheilidae)
}

\author{
José Heitzmann Fontenelle ${ }^{1,2}$; Luiz Ricardo L. Simone ${ }^{3}$ \& Daniel Caracanhas Cavallari ${ }^{4}$ \\ 1 Universidade Metropolitana de Santos (UNIMES). Santos, SP, Brasil. \\ ORCID: http://orcid.org/0000-0001-6718-5490. E-mail: josefontenelle@santos.sp.gov.br \\ 2 Parque Zoobotânico 'Orquidário Municipal de Santos'. Santos, SP, Brasil. \\ 3 Universidade de São Paulo (USP), Museu de Zoologia (MZUSP). São Paulo, SP, Brasil. \\ ORCID: http://orcid.org/0000-0002-1397-9823. E-mail: Irsimone@usp.br \\ ${ }^{4}$ Universidade de São Paulo (USP), Faculdade de Filosofia, Ciências e Letras de Ribeirão Preto (FFCLRP), \\ Departamento de Biologia (DB). Ribeirão Preto, SP, Brasil. \\ ORCID: http://orcid.org/0000-0003-3104-6434. E-mail: dccavallari@usp.br (corresponding author)
}

\begin{abstract}
Megalobulimus dryades sp. nov. is described from the Atlantic Forest in the Vale do Ribeira region, in the states of Paraná and São Paulo, S-SE Brazil, based on morphology. Representatives of the new species with white peristome and glossy periostracum have been misidentified as Megalobulimus gummatus (Hidalgo, 1870) since the $19^{\text {th }}$ (entury. The true M. gummatus is revised and redescribed, and its distribution is here restricted to Rio de Janeiro state. Externally, the new species differs from M. gummatus in having distinct protoconch color and sculpture, teleoconch sculpture marked by strong anastomosing rugosities and malleations, and lighter colored white-greyish head-foot. Internally, it presents distinct jaw and radular features, a talon, and a long convoluted penis bearing two flagella. Additional comparisons with other Brazilian congeneric species are also provided.
\end{abstract}

Keywords. Land snail; Rio de Janeiro; São Paulo; Paraná; Vale do Ribeira.

\section{INTRODUCTION}

Strophocheilid gastropods belonging to the subfamily Megalobuliminae Leme, 1973 and the genus Megalobulimus Müller, 1878 are the largest native South American Eupulmonata, with a shell length usually ranging from $50-160 \mathrm{~mm}$. There are currently 55 species recorded from Brazil (Simone, 2006; Birckolz et al., 2016), most of which are found in the Atlantic Forest. These snails are threatened with environmental destruction and contamination, a problem aggravated by their high regional endemism and the introduction of exotic species (Mansur \& Leme, 1996; Simone, 1999; Lydeard et al., 2004).

The two most extensive revisions of Strophocheilidae performed in the $20^{\text {th }}$ Century by Bequaert (1948) and Morretes (1952) were mostly based on shell characters and presented very distinct results and conclusions. Divergences between these revisions can be partly explained by intraspecific variation of terrestrial gastropod shells (Mayr, 1977). Leme (1971, 1973) argued that shell characters alone might be insufficient for comparative studies on Megalobulimus due to intraspecific variation and overlapping characters, but shell-based descriptions are still very frequent and substantial (e.g., Fontenelle et al., 2014; Simone, 2018). Even so, several works have consistently shown that more accurate conclusions can be drawn from associating shell characters with anatomical features, especially those focused on the digestive, reproductive, and excretory organs (Leme, 1989; Leme \& Indrusiak, 1995; Borda \& Ramirez, 2016). Ideally, such analyses should also include paleontological, ontogenetic, molecular, and ecological data, using a holomorphological approach (Leme, 1971; Wheeler, 2008).

In a wide-range comparative study on the number of recognizable species under different species concepts by Agapow et al. (2004), gastropods emerged as the only group that had a reduced number of species under the phylogenetic species concept compared to the biologi- 
cal concept. This indicates an excess of synonyms and a subsequent need for comprehensive revisions, which is especially true for Megalobulimus.

In a review of Megalobulimus specimens from the collection of the Museu de Zoologia da Universidade de São Paulo (MZSP), we found a seemingly consistent assemblage of individuals from São Paulo and Paraná states labeled as M. gummatus (Hidalgo, 1870). These individuals proved to be conchologically and anatomically divergent from populations of $M$. gummatus from the type locality in northern Rio de Janeiro state, which have shells similar to the holotype of M. gummatus (Fig. 10A-C). The southern individuals are introduced herein as a new species, and we provide a redescription of $M$. gummatus based on type material and specimens from Rio de Janeiro for comparative purposes.

\section{MATERIAL AND METHODS}

Specimens studied herein are deposited in the Mollusca Collection of the Museu de Zoologia da Universidade de São Paulo (MZSP). Shell measurements (Fig. 2C-D) and the number of shell whorls follow Bequaert (1948). Dissections were carried out following the methods of Leme (1973) and Simone \& Leme (1998). Radulae were spur-coated with gold and examined under SEM in the Laboratório de Microscopia Eletrônica, MZSP.

Abbreviations in figures: aa, anterior aorta; ac, albumen chamber; ad, anterior digestive gland; ae, anterior esophagus; ag, albumen gland; al, accessory glandular sac; an, anus; bc, bursa copulatrix; bm, buccal mass ceiling; br, subradular membrane; bt, hardened region of radular tissue preceding buccal region; cv, collar vessel; da, opening of the duct of anterior lobe of the digestive gland; $\mathbf{d b}$, bursa copulatrix duct; $\mathbf{d d}$, vas deferens duct; dp, duct of the posterior lobe of the digestive gland; ef, epi-renal plexus; eg, spermatic gutter; el, inner fold of epiphallus; eo, spermoviduct; ep, epiphallus; es, esophagus; et, esophageal typhlosole; fa, folds of albumen chamber; fl, flagellum; fo, free oviduct; gg, accessory glandular groove of spermoviduct; go, gonad; hd, hermaphroditic duct; ht, heart; ig, intestinal gutter; in, intestine; ip, inner penial folds; it, intestinal typhlosole; jw, jaw; ki, kidney; $\mathbf{m} \mathbf{2}$, retractor muscle of the buccal mass; m4-m5, dorsal tensor muscles of radula; $\mathbf{m 1 1}$, ventral tensor muscle of radula; $\mathbf{m 6}$, horizontal muscle; m7, pair of internal muscles of radular sac; me, middle esophagus; $\mathbf{m j}$, jaw muscles; $\mathbf{m p}$, retractor muscle of penis; np, nephrostome; nv, ad-renal vessels; oc, odontophore cartilage; ob, opening of the duct of bursa copulatrix; od, odontophore; ot, oral tube; p1-p5, folds of pre-valvar region of intestine; p6, longitudinal central post-valvar fold; p7, oblique post-valvar folds; pa, posterior aorta; pe, penis; pf, pyloric fold; pn, pneumostome; po, posterior esophagus; pd, pulmonary cavity deep; pt, prostate; pv, paleo-diaphragmatic muscle; ra, radula; rf, rectal folds; rt, rectum; rv, ad-rectal vessels; sa, salivary gland duct aperture; se, septum; sg, esophageal gutter; ta, talon; tf, inner transversal fold of penis; ot, oral tube; ug, ureteric groove; up, urinary papilla; ut, uterus; v1-v3, vessels of pulmonary vein; va, pre-rectal valve; ve, free oviduct appendix; vg, vagina; vp, pericardial vessel.

Abbreviations in text: BA: Bahia state; PE: Pernambuco state; RJ: Rio de Janeiro state; SP: São Paulo state; W: width. H: height; L: length; sh: shell(s); spm: specimen(s) with soft parts.

Institutional abbreviations: ANSP, Academy of Natural Sciences, Philadelphia, USA; FMNH, Field Museum of Natural History, Chicago, USA; FPZSP, Fundação Parque Zoológico de São Paulo, São Paulo, Brazil; MNCN, Museo Nacional de Ciencias Naturales, Madrid, Spain; MZSP, Museu de Zoologia da Universidade de São Paulo, São Paulo, Brazil; NIOO, Netherlands Institute of Ecology, Wageningen, Netherlands.

\section{RESULTS}

\section{Megalobulimus dryades sp. nov.}

(Figs. 1-8)

\section{http://zoobank.org/C413C457-BEF0-478E-8886-8F0CE9473724}

Strophocheilus gummatus: Morretes, 1949: 143 (in part, non Hidalgo).

Megalobulimus (Phaiopharus) gummatus: Morretes, 1952: 113, 1953: 65 (in part, non Hidalgo).

Megalobulimus gummatus: Leme, 1973: 318, fig. 38; Sobreira \& Molina, 2002; Salgado \& Coelho, 2003: 158 (in part); Simone, 2006: 211, fig. 804 (in part); Thomé et al., 2007: 22 (in part); Agudo-Padrón, 2010: 35, fig. 2, 2011: 61, fig. 2; Birckolz et al., 2016: 150 (non Hidalgo).

Type specimens: Holotype: MZSP 120000 (J.L.M. Leme col., 01/vii/1961).

Paratypes: BRAZIL. São Paulo; Iporanga, MZSP 15594, 13 spm (J.L.M. Leme col., 01/vii/1961); Guapiará, Fazenda Intervales, MZSP 28925, 2 sh (MZSP Exp., 22-26/iii/1992); Iguape, Núcleo Despraiado, MZSP 28773, 2 sh (R.P. Rocha,

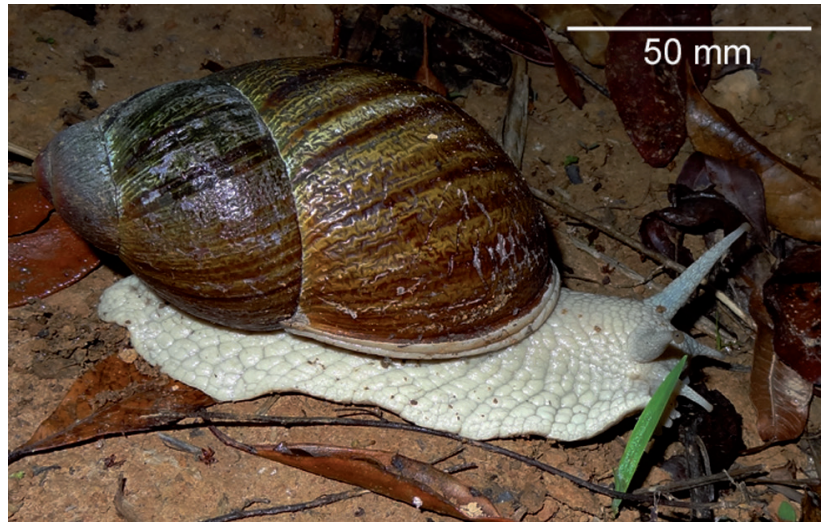

Figure 1. Megalobulimus dryades sp. nov., live specimen in the Atlantic Forest, Fazenda Intervales, São Miguel Arcanjo Municipality, São Paulo state (photo by B.M. Tomotani) 


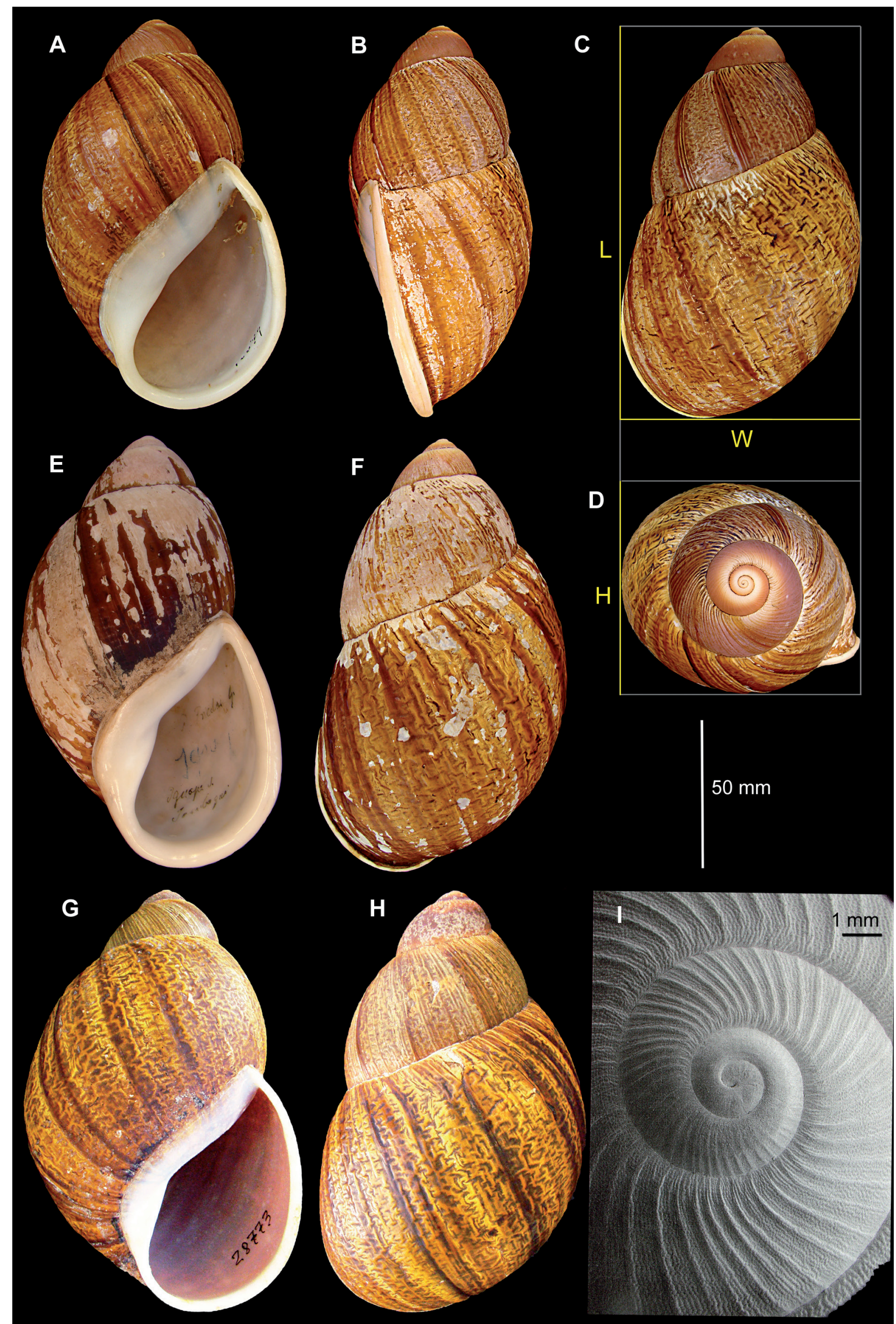

Figure 2. Shell of Megalobulimus dryades sp. nov.: (A-D) holotype (MZSP 120000, Iporanga, SP), (A) apertural view, (B) lateral view, (C) abapertural view, (D) apical view; $C$ and D showing the shell measurements: $\mathrm{L}=$ length, $\mathrm{W}=$ width, $\mathrm{H}=$ height; (E-F) paratype (MZSP 29317, Iguape, SP), (E) apertural view, (F) abapertural view; (G-H) paratype (MZSP 28773, Iguape, SP), (G) apertural view, (H) abapertural view; (I) paratype (MZSP 15594), apical view of protoconch in SEM. 
Bertani \& Mestre cols., 03/x/1997), MZSP 28893, 2 spm (N. Moraccioli col.), MZSP 29317, 2 sh (R. Krone col., 1901). Paraná; Morretes, MZSP 16610, 2 sh (Lange de Morretes col.).

Type locality: Brazil, São Paulo state, Iporanga Municipality (center coordinates $24^{\circ} 35^{\prime} \mathrm{S}, 48^{\circ} 35^{\prime} \mathrm{W}$ ), $\sim 80 \mathrm{~m}$ of elevation.

Material examined (non-types): BRAZIL. São Paulo; Sorocaba, MZSP 62129 (1 sh); Mogi das Cruzes, MZSP 28962 (1 sh); Itapecerica da Serra, MZSP 15724 (1 sh); São Sebastião, MZSP 96475 (2 sh); Cubatão, MZSP 64563 (1 sh); Juquetiba, MZSP 92832 (2 sh); Tapiraí, MZSP 16039 (5 sh); São Vicente, MZSP 16615 (1 sh); Itapeva, MZSP 29320 (1 sh), MZSP 96474 (2 sh); Itanhaém, MZSP 42350 (1 sh), MZSP 92833 (1 sh); Guapiará, MZSP 29316 (1 sh); Fazenda Intervales, MZSP 30460 (1 sh); Miracatu, MZSP 49935 (1 spm), MZSP 49936 (1 spm), FPZSP, MZSP 49937, (1 spm), MZSP 49940 (1 spm), MZSP 49941 (1 spm), MZSP 49942 (1 spm), MZSP 49944 (1 spm), MZSP 49945 (1 spm); Pedro de Toledo, MZSP 92837 (1 sh); Itariri, MZSP 48256 (1 spm), MZSP 96477 (2 sh); Peruíbe, MZSP 29309 (1 sh); Biguá, MZSP 92836 (1 sh); Juquiá, MZSP 269 (3 sh), MZSP 90913 (1 sh), MZSP 90914 (1 sh), MZSP 96478 (1 sh), MZSP 96479 (1 sh); Registro, MZSP 48523 (1 sh); Eldorado Paulista, MZSP 29315 (2 sh); Iporanga, MZSP 7996 (1 sh), MZSP
15603 (2 sh), MZSP 15617 (4 sh), MZSP 33031 (8 sh), MZSP 43529 (1 sh), MZSP 43533 (1 sh), MZSP 43689 (1 sh), MZSP 43697 (1 sh), MZSP 92835 (1 sh); Jacupiranga, MZSP 32541 (1 sh); Iguape, MZSP 29311 (1 sh), MZSP 29312 (4 sh), MZSP 71070 (1 sh); Pariquera-açú, MZSP 29313 (1 sh), MZSP 29318 (1 sh). Paraná; Sengés, MZSP 16603 (10 sh).

Diagnosis: Shell large, with strong rugosities and malleated surface on teleoconch whorls; protoconch darker-colored with a clear lighter subsutural band, with microsculpture consisting of granules and macroscuIpture of well-marked axial riblets that branch apically near suture. Peristome homogeneously white, columella oblique and slightly convex. Head-foot very light-colored, dirty white to grayish-bluish; free oviduct appendix present; penis long and uniform with convolutions, lacking developed transverse fold, bearing two short flagella of similar length.

\section{Description}

Shell (Figs. 1-2): Large ( $\mathrm{L} \sim 119 \mathrm{~mm})$, oval, thick, of $\sim 5.4$ whorls, imperforate to semiperforate; profile strongly convex, moderately dorso-ventrally compressed $(\mathrm{H}: \mathrm{W}=0.8)$ (Fig. 2D); spire short and obtuse; usually not covered by periostracum in adults; color reddish ocher with yellowish-white subsutural band, ranging until last

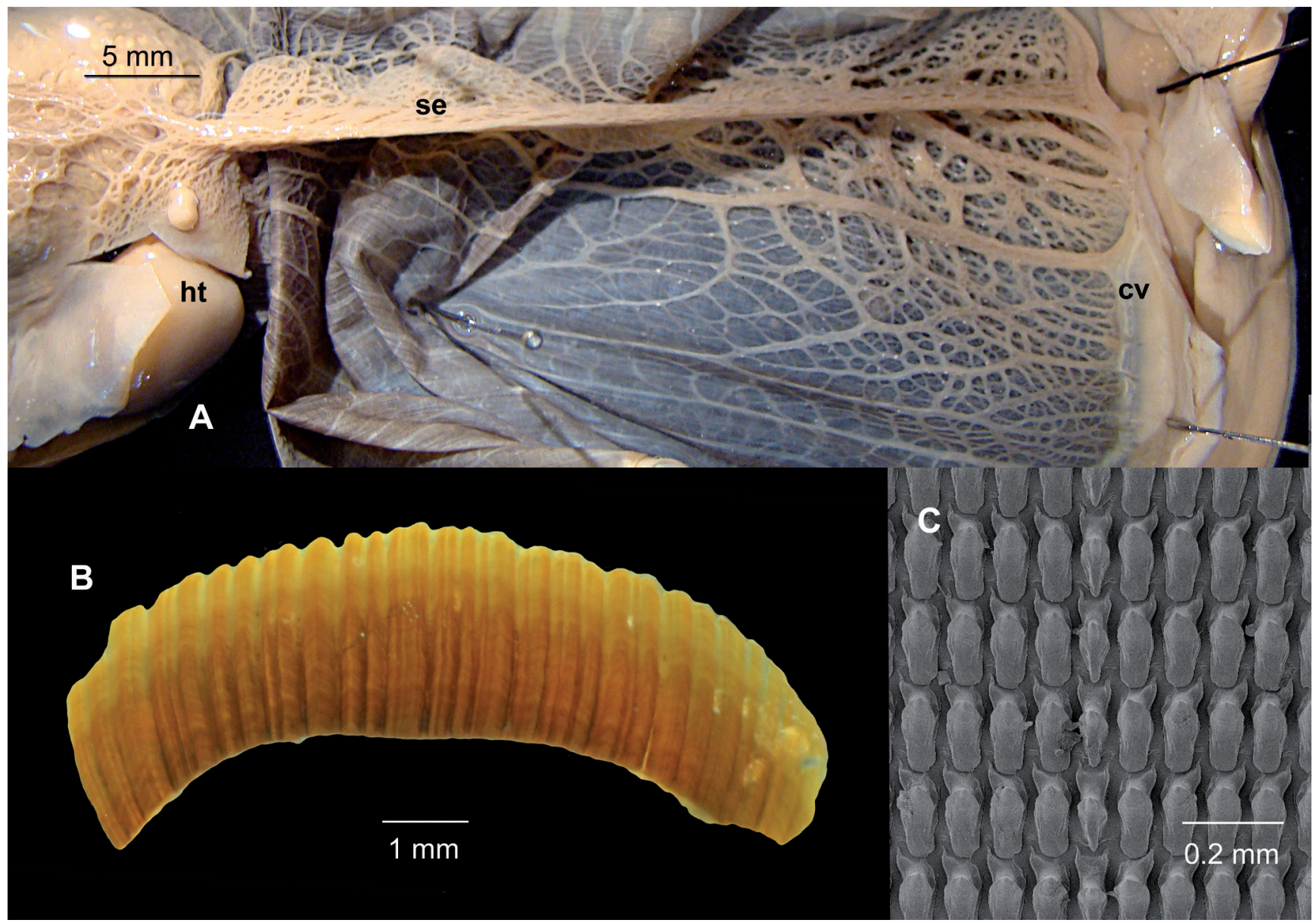

Figure 3. Megalobulimus dryades sp. nov. anatomy: (A) pulmonary (pallial) cavity, ventral-inner view showing collar vessel (cv), septum (se), heart (ht); (B) jaw, anterior view, left side damaged; (C) radula, central region in SEM. 
whorl. Protoconch (Fig. 2D, I) with $~ 3.2$ whorls, weakly convex, usually darker than teleoconch, reddish-darkbrown with a clearly marked white-cream subsutural band; first $1 \frac{11}{4}$ whorl smooth, followed by regular, complete prosocline riblets that branch apically near the suture, interspaces $2-3 \times$ wider than riblet width, presenting microscopic radial granulation that gradually increases in size toward final nepionic whorls (Fig. 2l). First $1 / 4$ teleoconch whorl with regular, thin riblets that are gradually replaced by delicate anastomosing rugosities and malleations that become larger, stronger, and coarser toward the last adult whorls $\left(4 \frac{1}{2}-5\right)$. Body whorl inflated, sculpture mostly consisting of strong rugosities and malleations (Fig. 2G-H), but also presenting irregular, widely spaced axial riblets and short radial striae interconnected with the other sculpture elements. Aperture oval (Fig. $2 A, E, G$ ), length $\sim 50 \%$ of shell length; peristome thickened and slightly reflected, outer lip arched,

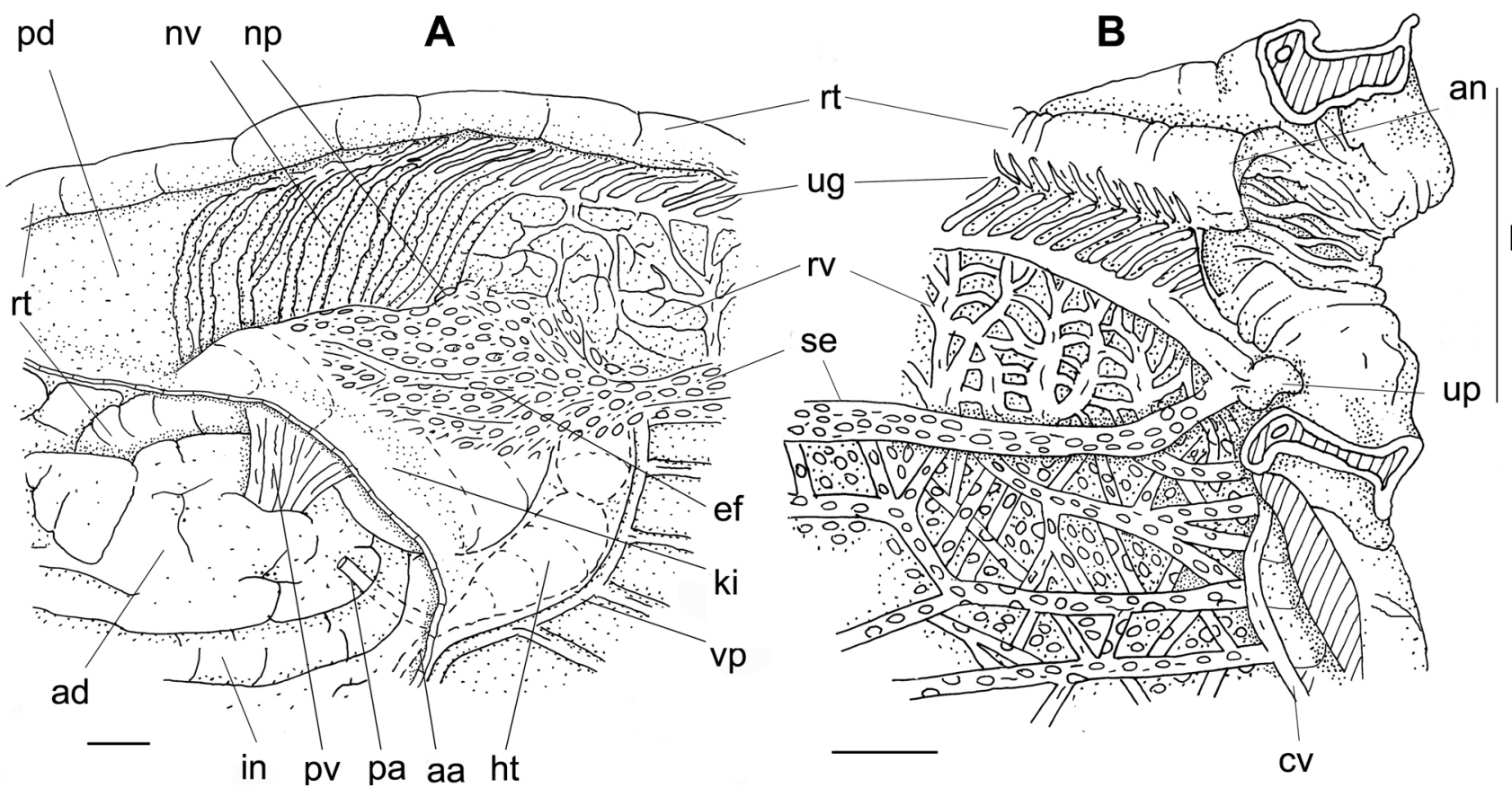

Figure 4. Megalobulimus dryades sp. nov. anatomy: (A) pallial chamber, renopericardial region, ventral view; (B) pneumostome region, ventral view, inner lip or pneumostome deflected. Scale bars $=5 \mathrm{~mm}$.

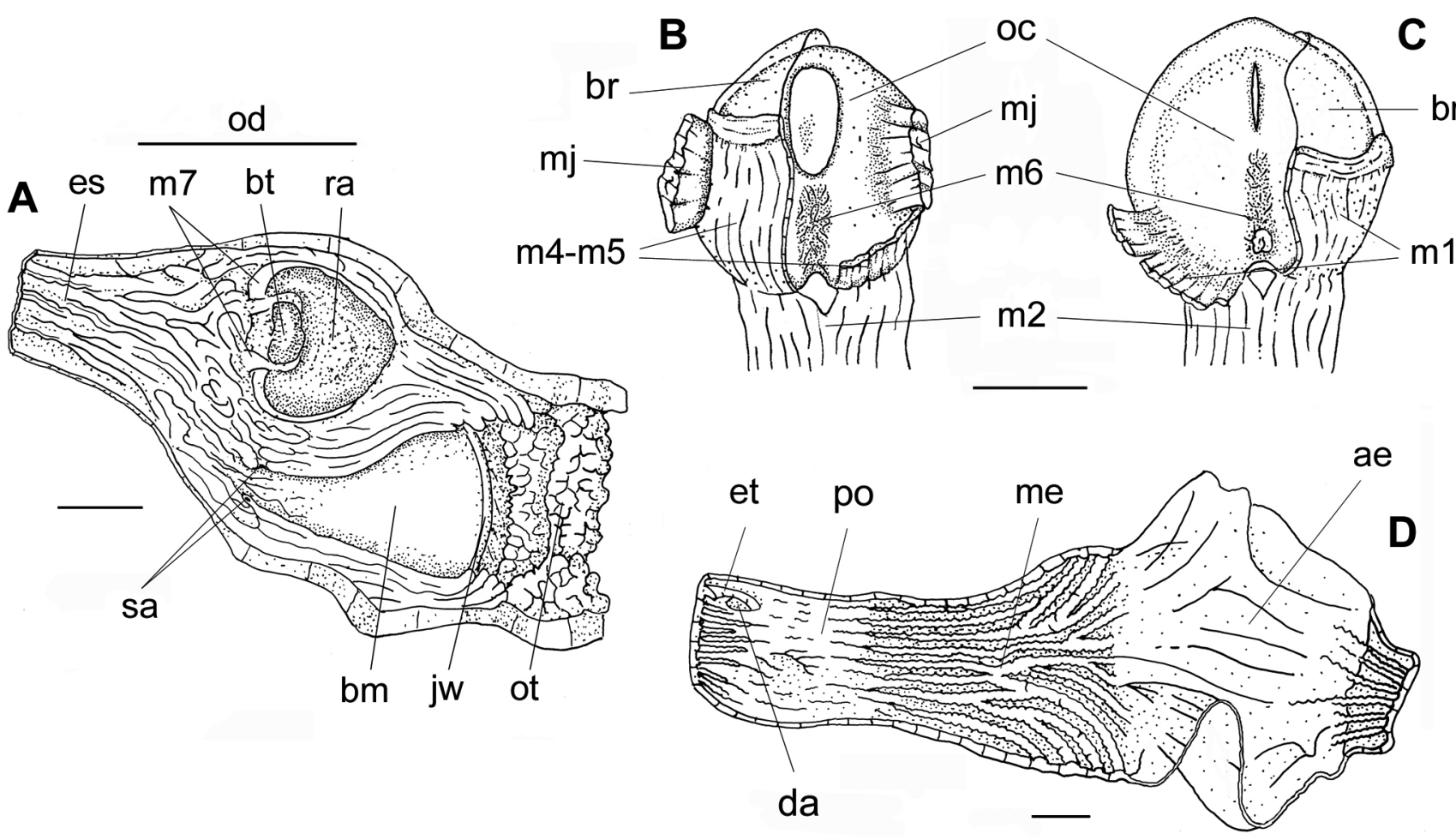

Figure 5. Megalobulimus dryades sp. nov. anatomy: (A) buccal mass opened longitudinally; (B) odontophore, dorsal view, radula and right muscles partially removed; (C) same, ventral view; (D) esophagus longitudinally opened, exposing its inner surface. Scale bars $=5 \mathrm{~mm}$. 
color white; columella thick, oblique, and slightly convex. Periostracum yellowish-brown, with dark radial bands in the interspaces between axial sculpture elements (Fig. 2G-H), and often darker colored in the malleation cavities; usually preserved on last two teleoconch whorls, with a glossy aspect when present (Fig. $2 \mathrm{H}$ ).

Head-foot: Tegument in living specimen very light-colored, from dirty white to grayish-bluish (Fig. 1); each buccal flange bearing seven papillae.

Pulmonary (pallial) cavity: Plexus of vessels containing divisions and anastomoses of collar vessel tributaries (Figs. 3A, 4B: cv) triangular, of radicular aspect, occupying $\sim 2 / 5$ of cavity volume, located between mantle edge and septum. Cardiac area occupying $\sim 1 / 3$ of reno-pericardial area (Fig. 4A: ht), with equidistant insertions of tributaries of pericardial vessel (Fig. 4A: vp). Insertion of palio-diaphragmatic muscle (Fig. 4A: pv) in angular pulmonary cavity deep in kidney (Fig. 4A: pd). Pulmonary septum (Figs. 3A, 4A, B: se) separating excretory/respiratory areas, covered by plexus of vessels, extending through middle surface of reno-pericardial area (Fig. 4A: ef). Pneumostome with strong anal folds anastomoses extending toward its inner edge.

Excretory system: Kidney (Fig. 4A: ki) sub-triangular, occupying $\sim 1 / 2$ of pulmonary septum volume, with protuberance at edge close to nephrostome (Fig. 4A: np) near transition between adrenal vessels (Fig. 4A: nv) and ad-rectal vessels (Figs. 4A, B: rv). Ureter absent. Folds of urinary gutter (Figs. 4A, B: ug) beginning near nephrostome level, flanking left side of rectum towards pneumostome (Fig. 4B: pn), partially covering rectum at its final half (Fig. 4B: rt), ending before anus.

Digestive system: Buccal mass robust (Fig. 5A: ot), retractor muscle inserted laterally in radular pouch.

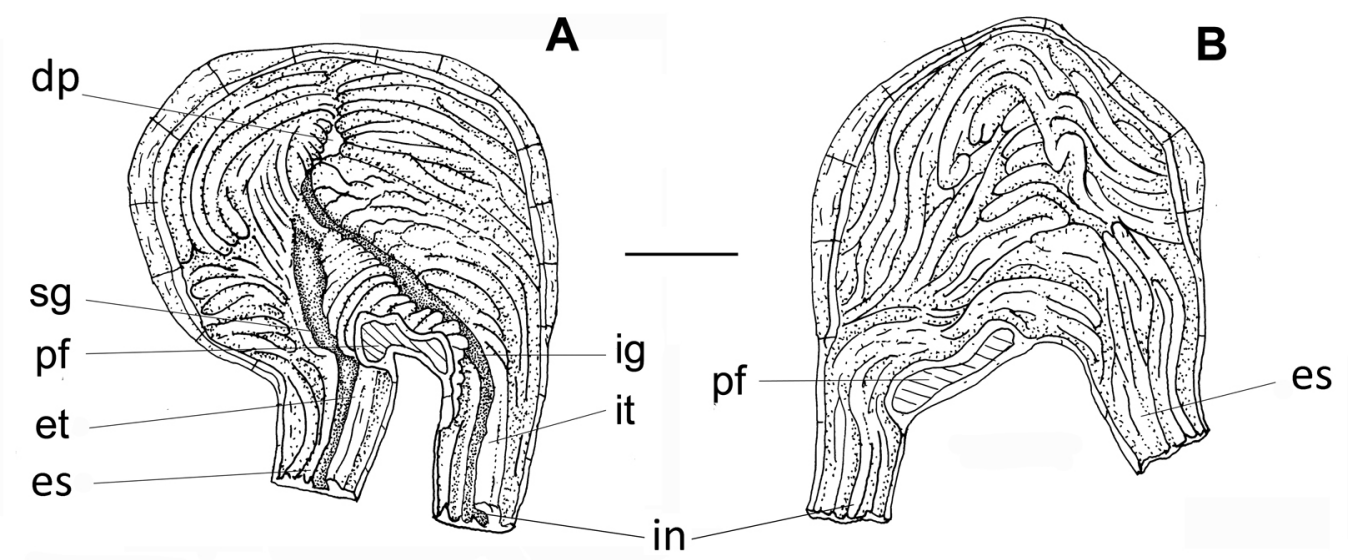

es
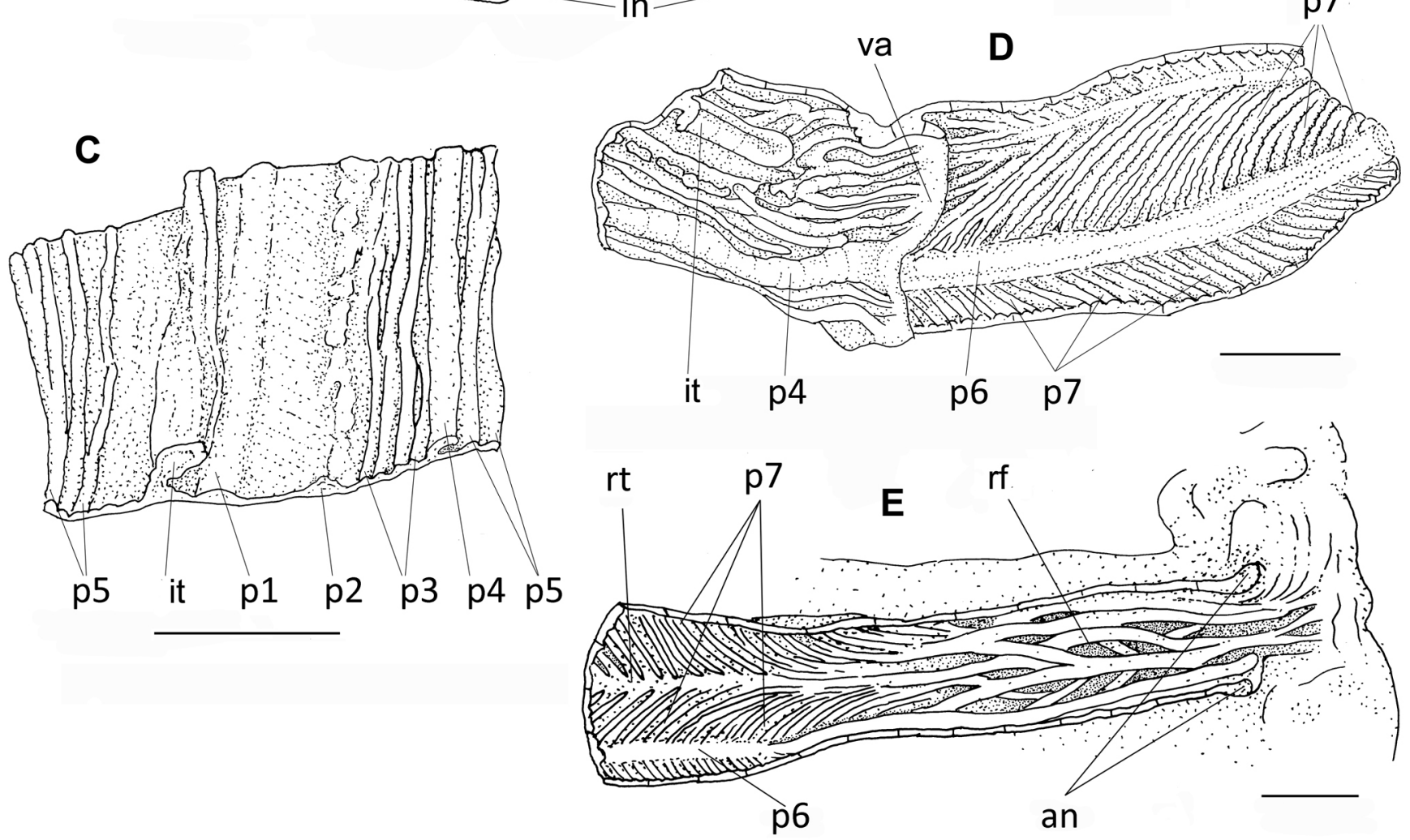

Figure 6. Megalobulimus dryades sp. nov. anatomy: (A) stomach, right view, opened longitudinally along dorsal surface; (B) same, left view; (C) intestine, transversally opened strip of its proximal region, inner surface exposed; (D) same, region of the pre-rectal valve; (E) same, rectum region. Scale bars $=5 \mathrm{~mm}$. 
Odontophore rounded (Fig. 5A: od), occupying $\sim 1 / 4$ of buccal mass volume. Aperture of salivary gland ducts (Fig. 5A: sa) located distally and laterally on ceiling of buccal mass (Fig. 5A: bm). Jaw arc-shaped, rigid, elasmognate, pigmented (Figs. 3B, 5A: jw), with 35 irregular, narrow and well-marked axial columns and transverse growth lines. Pair of muscles $\mathrm{m} 7$ surrounding radular sac in region preceding exposed radula, anteriorly protected by hardened tissue (Fig. 5A: bt); dorsal surface of odontophore cartilages rigid and darker-colored (Fig. 5B-C: oc), with groove obstructed by elliptical scar. Horizontal muscle (Figs. 5B-C: m6) connecting midline of odontophore cartilages; length $\sim 1 / 2$ of cartilage length. Fusion of main and secondary dorsal tensor muscles of radula

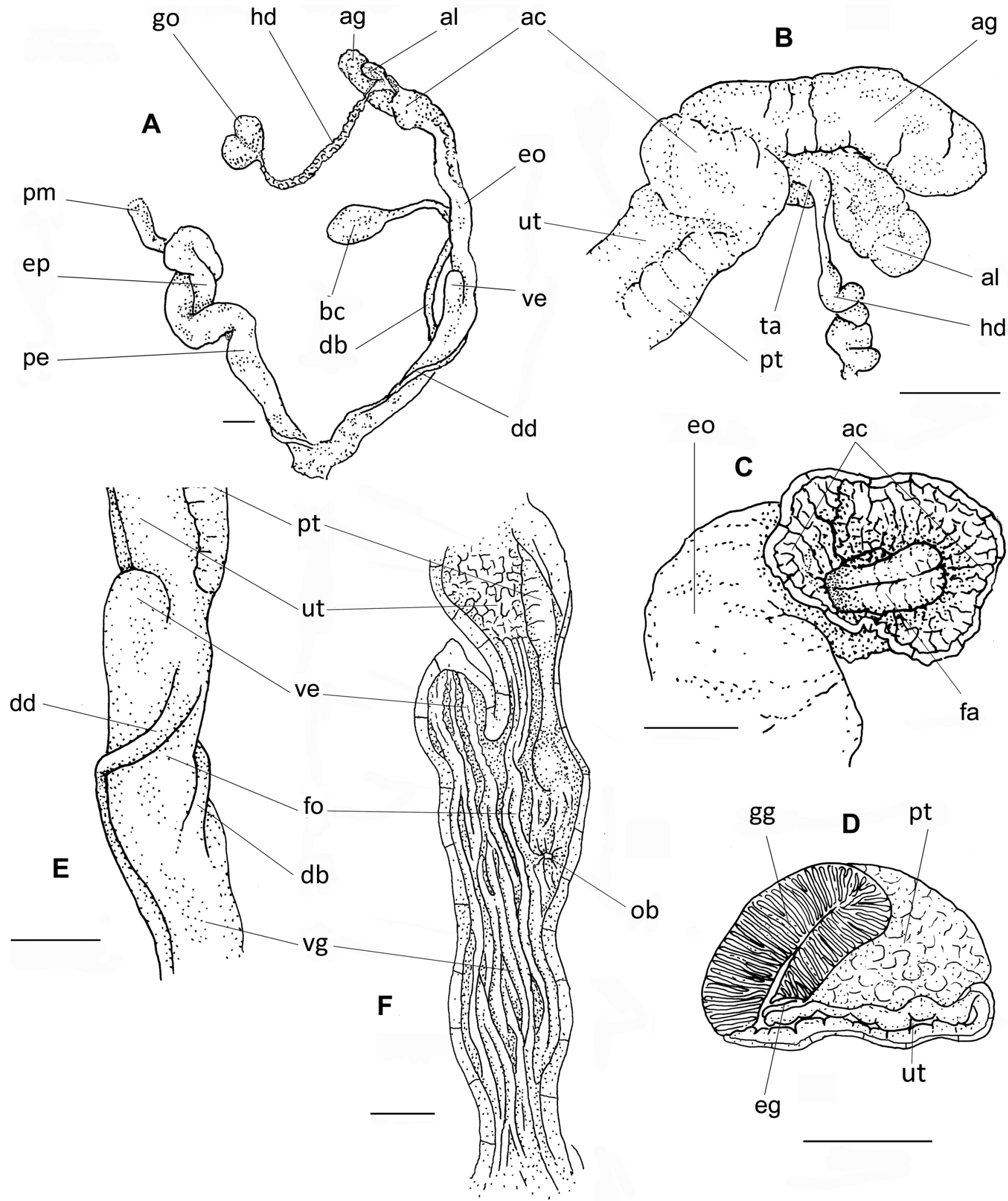

Figure 7. Megalobulimus dryades sp. nov. anatomy: (A) genital system, complete dorsal view; (B) Carrefour region, ventral view; (C) albumen chamber opened, exposing its folds; (D) spermoviduct, cross-section at its middle region; (E) anterior region of genital ducts, lateral view; (F) same, opened longitudinally. Scale bars = $5 \mathrm{~mm}$. 

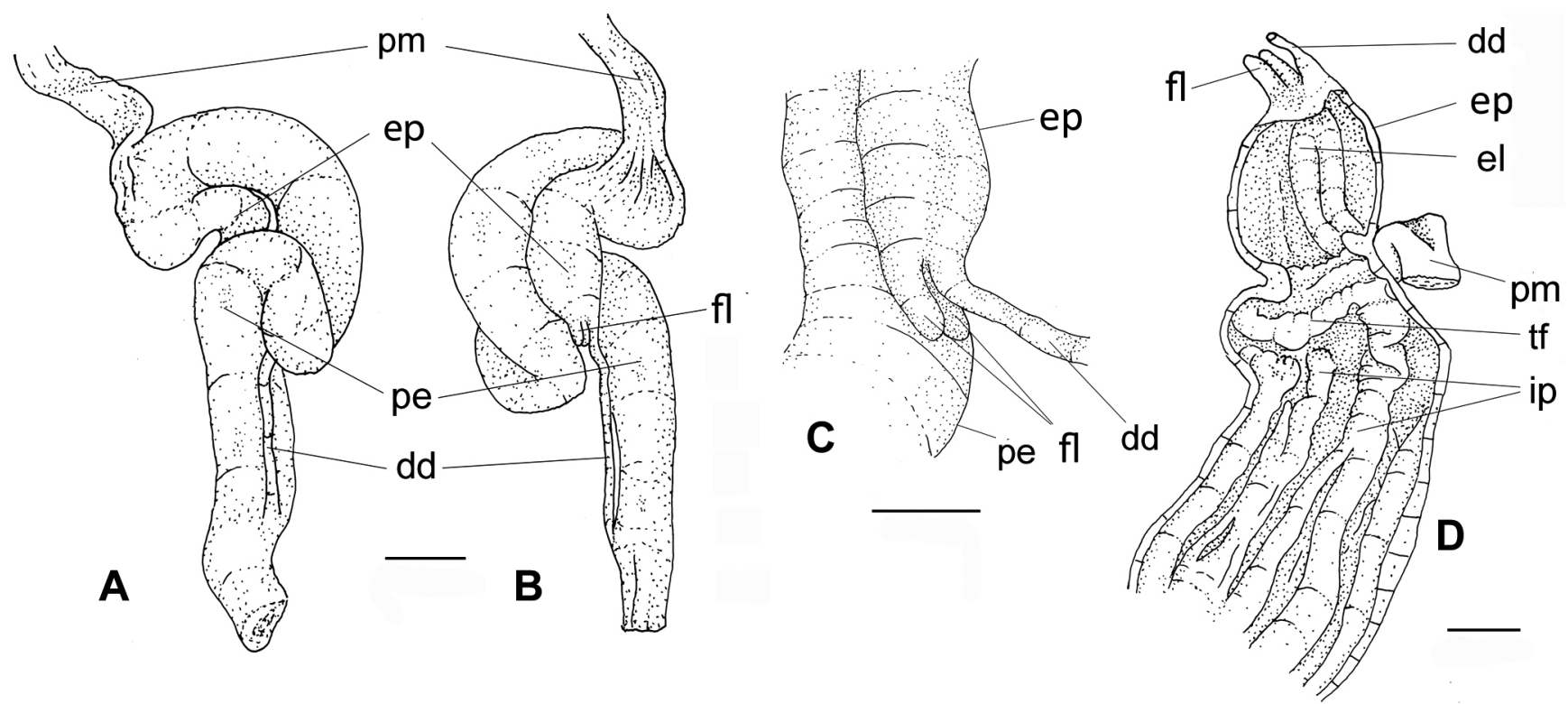

Figure 8. Megalobulimus dryades sp. nov. male structures: (A) penis and epiphallus, anterior view; (B) same, posterior view; (C) detail of epiphallus and its flagella; (D) penis and epiphallus opened longitudinally to expose their inner folds. Scale bars $=5 \mathrm{~mm}$.

(Fig. 5B: m5-m4) originating at anterior margin of cartilage, ventral tensor muscle of radula (Fig. 5C: $\mathrm{m} 11$ ) along insertion of retractor muscle of buccal mass (Fig. 5B: m2), both inserting respectively in subradular membrane (Fig. 5B-C: br). Jaw muscles (Fig. 5B: mj) originating at lateral margin of cartilage, surrounding oral tube dorsally.

Radula (Fig. 3C): With $~ 130$ rows of isolated unicuspidate teeth (64-1-64); central tooth 25\% smaller than laterals, drop-shaped with posterior apex, basal plate with long apical extensions forming acute angles; lateral teeth elliptical, 2 times as long as wide, with single, short, obtuse cusp; basal plate coniform, with an acute lateral extension.

Anterior chamber of esophagus (Fig. 5D: ae) occupying $\sim 1 / 2$ of esophagus volume, with thin, translucent wall; inner surface smooth, lacking folds. Salivary glands clustering around anterior esophagus. Middle esophagus (Fig. 5D: me) with strong longitudinal muscular folds, anastomosed distally. Posterior esophagus chamber-like (Fig. 5D: po), with inner serpiginous folds increasing in number at final third, located at opening of duct to anterior lobe of digestive gland (Fig. 5D: da) alongside emersion of esophageal typhlosole (Fig. 5D: et). Stomach rounded, walls thick, muscular, internally (Figs. 6A-B) covered by muscular folds and a bulging pyloric fold (Fig. 6A-B: pf) parallel to minor gastric curvature; pyloric fold surrounding both esophageal gutter (Fig. 6A: sg) originating at end of esophageal typhlosole (Fig. 6A: et) and intestinal gutters (Fig. 6A: ig) originating at aperture of duct of posterior lobe of digestive gland (Fig. 6A: dp), running into intestine (Fig. 6A: in).

Inner surface of proximal intestine with large intestinal typhlosole (Figs. 6C-D: it) and parallel folds (p1-p5); distance between folds p1 and p2 slightly wider; fold p4 (Figs. 6C-D: p4) reaching pre-rectal valve (Fig. 6D: va), continuing as post-valve central longitudinal fold, low and wide (Fig. 6D: p6), surrounded by oblique, post-valvar compact folds (Figs. 6D-E: p7). At final third of rectum
(Fig. 6E), fold p6 extinguishing, p7 folds becoming anastomosed into four bulging rectal folds (Fig. 6E: rf), progressing in part beyond aperture of anus (Fig. 6E: an) into inner edge of pneumostome.

Genital system: hermaphroditic duct (Figs. 7A, B: hd) inserting apically into talon (Fig. 7B: ta) at base of accessory glandular sac (Fig. 7B: al). Carrefour (Fig. 7B) located medially in albumen gland (Figs. 7A, B: ag). Albumen chamber (Figs. 7A, B, C: ac) with two inner voluminous folds (Fig. 7C: fa), forming groove running toward uterus. Spermoviduct (Figs. 7A, C: eo, D) bearing accessory glandular groove (Fig. 7D: gg); uterus (Figs. 7B, D: ut), spermatic gutter (Fig. 7D: eg) and narrow prostate (Figs. 7B, D: pt) occupying $\sim 1 / 4$ of perimeter. Free oviduct and vagina (Figs. 7E, F: ol, vg) uniformly tubular, limited distally by robust free oviduct appendix (Figs. 7A, E: ve), size well over half of free oviduct size. Inner muscle folds of free oviduct and vagina perpendicular and slightly directed to opening of duct of bursa copulatrix (Fig. 7F: ob). Bursa copulatrix duct wide and flattened (Figs. 7A, E: db); bursa copulatrix balloon-like (Fig. 7A: bc), with thick muscular walls, bearing internal folds transversal to duct insertion.

Penis long and uniformly cylindrical (Figs. 7A, 8A: pe), same diameter as free oviduct, drawn and coiled by traction of vas deferens (Fig. 8A: dd). Inner penial folds (Fig. 8C: ip) longitudinal, with anastomoses, bearing low transverse fold near its tip (Fig. 8C: tf), not bulky or pedunculated. Epiphallus broad and short (Figs. 8A-D: ep), $\sim 1 / 5$ of penis length, with two uniform and short flagella (Figs. 8A, C-D: fl), and two inner folds (Fig. 8D: el). Penis muscle sub-apical (Figs. 8A, D: mp).

Distribution and habitat: Megalobulimus dryades sp. nov. was initially recorded in the Vale do Ribeira region, in São Paulo state. It is found mainly in the middle and lower Rio Ribeira do Iguape Basin in southern São Paulo and northeastern Paraná states (Fig. 9). Apparently, 
this species has a high environmental tolerance, and its range may have been expanded by humans who used its shells in handicrafts. Agudo-Padrón $(2010,2011)$ recorded its presence in Santa Catarina state, identified as M. gummatus (non Hidalgo).

Ecology: Sobreira \& Molina (2002) studied the reproduction of M. dryades sp. nov. (referred to as M. gummatus in their study) based on three specimens from Vale do Ribeira. Egg-laying occurred in two periods, a longer one between April and May and a shorter one between September and November. Specimens laid 2 to 5 eggs per clutch, with average hatching of $52.4 \%$ after a development period of 60 days $(n=21)$. The mean egg size was $28.6 \times 21.3 \mathrm{~mm}(\mathrm{n}=26)$.

Etymology: The comprehensive classification of the Brazilian phytogeographic regions proposed by Carl
Friedrich Philipp von Martius (1840-1869) divided the country into phytogeographic provinces named after nymphs from Greek mythology. The name Dryades was used to designate the region roughly corresponding to the current Brazilian Atlantic Forest. This biome has been reduced to about $15 \%$ of its original territorial coverage. The Vale do Ribeira region is the largest continuous reserve of this threatened biome, thus our inspiration for the specific epithet, which is used herein as a noun in apposition.

Measurements: Holotype, L: $119 \mathrm{~mm}$; W: $70 \mathrm{~mm}$; $\mathrm{H}: 57 \mathrm{~mm}$; S: 5.5 ; P: 3.5; Paratypes ( $n=23$; \pm standard deviation) L: $118 \pm 8 \mathrm{~mm}$; W: $72 \pm 4 \mathrm{~mm}$; H: $54 \pm 3 \mathrm{~mm}$; S: $5.4 \pm 0.2 ; \mathrm{P}: 3.2 \pm 0.2$.

Remarks: The first shells of $M$. dryades sp. nov. were collected by naturalist Adolph Hempel and archaeologist Ricardo Krone (Paratype on Fig. 2E-F) in the Vale do

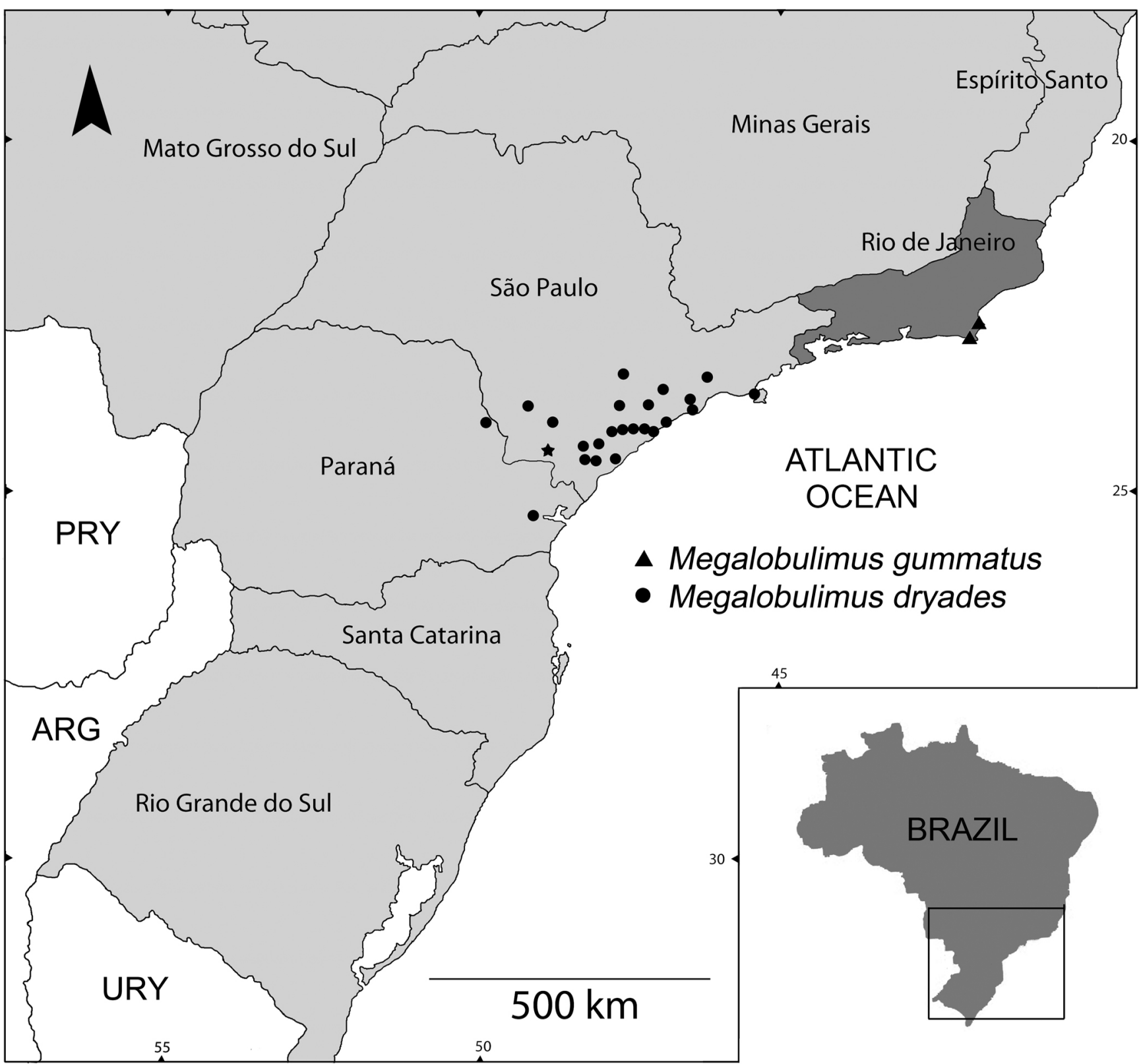

Figure 9. Megalobulimus dryades sp. nov. and M. gummatus in S-SE Brazil: Geographical distributions based on MZSP specimens. Megalobulimus dryades sp. nov. (circles; star indicating type locality, Iporanga) in south São Paulo state; M. gummatus (triangle) on the central coast of Rio de Janeiro state (type locality). 
Ribeira region in the late $19^{\text {th }}$ - early $20^{\text {th }}$ centuries, and were deposited in the Museu Paulista (currently MZSP). When Morretes $(1949,1953)$ published his catalog of mollusks from Brazil, he considered those samples as representatives of southern populations of $M$. gummatus inhabiting the states of São Paulo and Paraná. This concept was maintained in subsequent compilations (Salgado \& Coelho, 2003; Simone, 2006). Meanwhile, the concomitant erroneous use of another name, Megalobulimus chionostoma (Mörch, 1852), to refer to true M. gummatus specimens caused further taxonomic confusion.

Apart from the white peristome and a glossy periostracum, the shells of $M$. dryades sp. nov. and M. gummatus present some coincidental features such as large size, a dorsoventrally compressed outline, similar protoconch macrosculpture, and pigmented shell matrix with a white subsutural band (Figs. 2D, 10). However, M. dryades sp. nov. differs in having a darker protoconch with a clearly marked lighter subsutural band, with a sculpture lacking any distinct spiral elements, consisting of more pronounced axial riblets that branch apically near the suture, and microscopic granules. It also has a lower spire, a body whorl with a strongly corrugated surface with malleations, a less reflected but thicker peristome with a more rounded outer lip, and a thicker, oblique, and slightly convex columella.

The soft parts of $M$. dryades sp. nov. are lighter-colored externally compared to $M$. gummatus. Internally, differences in the digestive system reside in the more robust mandible with narrow, well-marked columns, and the configuration of the radular teeth. The genital systems are also distinct, as $M$. dryades sp. nov. has a long and uniform penis and an epiphallus bearing two flagella. The presence of a talon and a free oviduct appendix further distinguishes it from M. gummatus, which in turn seems more closely related to species of the so-called "M. ovatus species complex" sensu Leme $(1989,1993)$ due to the lack of these two last characters. Finally, both species present isolated distributions and distinct habitats (see M. gummatus, below).

\section{Megalobulimus gummatus (Hidalgo, 1870)}

(Figs. 10-12)

\section{Synonymy see Bequaert (1948). Complement:}

Bulimus gummatus Hidalgo, 1870: 41.

Strophocheilus (Megalobulimus) terrestris gummatus: Bequaert, 1948: 115, pl. 17, fig. 6; Mello \& Coelho, 1989: 378.

Strophocheilus gummatus: Morretes, 1949: 143; Templado et al., 1993: 92.

Megalobulimus (Phaiopharus) gummatus: Morretes, 1952: 113, 1953: 65.

Megalobulimus gummatus: Salgado \& Coelho, 2003: 158 (in part); Breure \& Araujo, 2017: 103, fig. 38-B.

Types: Holotype: BRAZIL, Rio de Janeiro, MNCN 15.05/3199, 1 sh (Paz col., xi/1862) (Fig. 10A-C).
Type locality: Rio de Janeiro State.

Material examined: Holotype. Additional material: Brazil, MZSP 94172 (3 sh); Rio de Janeiro, Cabo Frio, MZSP 34703 (5 sh), MZSP 92424 (2 sh), MZSP 29374 (2 sh); Arraial do Cabo, MZSP 73766 (2 sh), MZSP 34420 (1 spm), MZSP 34421 (1 spm), MZSP 34422 (1 sh), MZSP 34223 (1 spm), MZSP 66800 (3 sh).

Diagnosis: Shell large, glossy and thin; protoconch presenting microsculpture consisting of granules and spiral lines, and macrosculpture consisting of delicate axial riblets and spiral threads that are more apparent on last nepionic whorl. Teleoconch sculptured by thin axial growth lines intercrossed by spiral cords, producing a reticulate aspect; peristome pure white; columella slightly concave. Head-foot whitish to light gray; talon and free oviduct appendix, absent, free oviduct short, penis clavate, and epiphallus without flagella.

\section{Distinctive description}

Shell: (Fig. 10) large (L 111 mm), light and oval, dorso-ventrally compressed, with $\sim 5.3$ strongly convex whorls, apex obtuse, body-whorl dislocated to left in relation to columellar axis. Protoconch (Figs. 10G, J) with 3.5 whorls, color usually darker than teleoconch, dark yellow, orange or pinkish, with a diffuse lighter subsutural spiral band (Fig. 10G); first half whorl smooth, remaining whorls sculptured by prosocline axial riblets with wide interspaces (2-4x riblet width), and spiral threads that are more apparent on last nepionic whorl, occasionally producing distinguishable sulci (Fig. 10G, J, arrows); microscopic sculpture consisting of spiral lines and granules. Penultimate teleoconch whorl and body whorl sculptured by thin axial riblets intercrossed by low spiral cords, producing reticulate aspect, with spiral cords becoming more conspicuous towards body whorl (Fig. 10B, E, H). Aperture (Fig. 10A, F, H-I) semi-oval, length $50 \%$ of shell length, peristome homogeneously white, strongly reflected (Fig. 10E), not particularly thick, forming channel external to aperture; outer lip more straight and attached to body whorl in an open angle, inner lip long; columella narrow, straight and oblique. Periostracum glossy, yellowish (Fig. 10A-C, H) brown (Fig. 10D-F, I) with darker axial bands, deciduous (Fig. 10F), persistent on last two whorls.

Head-foot: Tegument yellowish to light gray.

Pulmonary (pallial) cavity: Insertion of paleo-diaphragmatic muscle (Fig. 12A: pv) on angular cardiac of kidney. Pneumostome with sparce anal folds not extending toward its inner edge (Fig. 12B: pn).

Excretory system: Kidney (Fig. 12A: ki) triangular, size $\sim 1 / 3$ of pulmonary septum size. Urinary gutter folds not spread over rectum.

Digestive system: Buccal mass less robust; jaw equally rigid, elasmognate and pigmented (Fig. 11A) with $\sim 17$ 


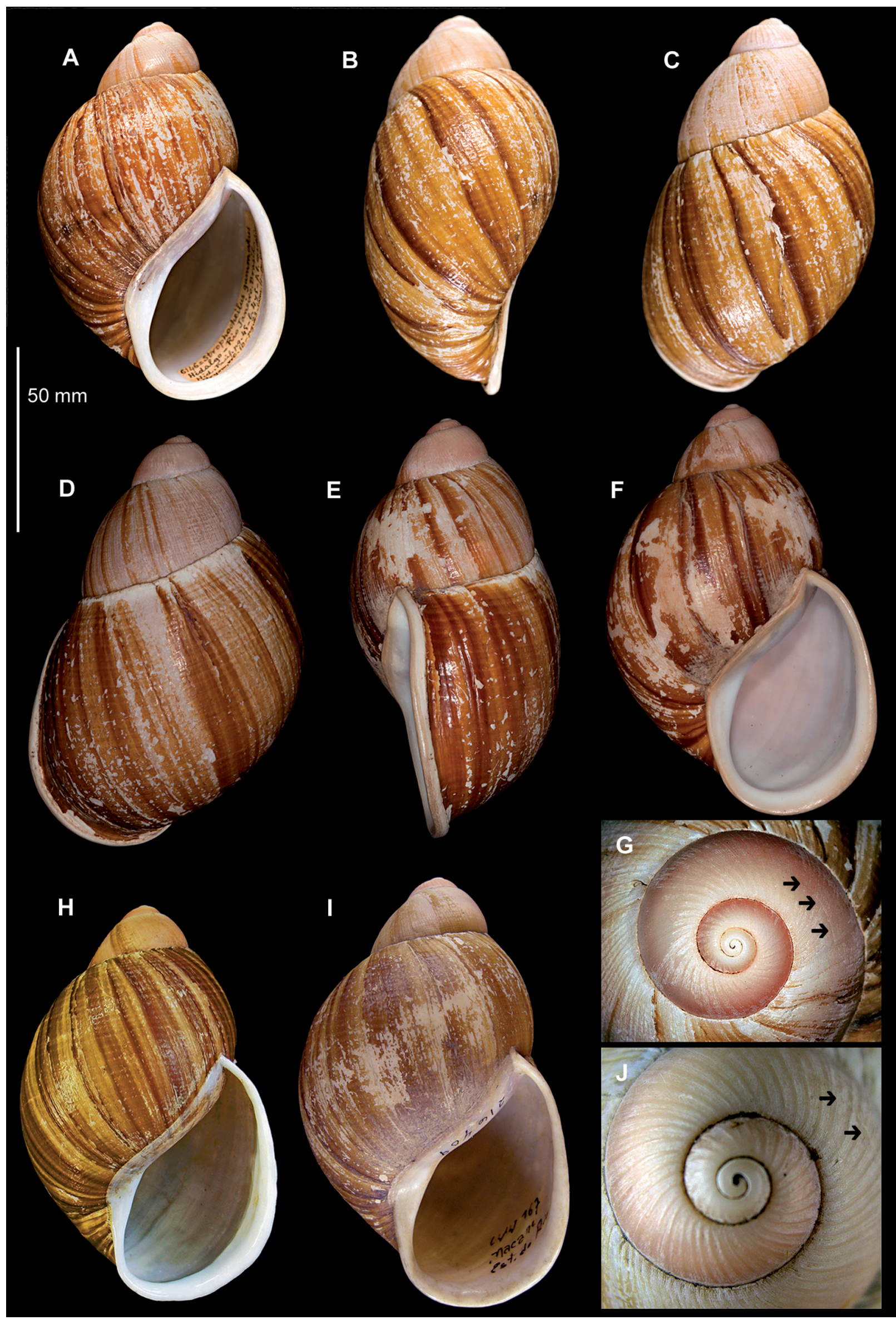

Figure 10. Shells of Megalobulimus gummatus: (A-C) holotype MNCN 1505/3199 (Rio de Janeiro), (A) apertural view, (B) lateral view, (C) abapertural view; (D-G) ANSP 428461 (Rio de Janeiro), (D) abapertural view, (E) lateral view, (F) apertural view, (G) protoconch; (H) MZSP 66800 (Arraial do Cabo, RJ), apertural view; (I-J) FMNH 216409 (Macaé, RJ, det. Bequaert, 1953), (I) apertural view, (J) protoconch. Arrows indicate location of spiral sulci. 


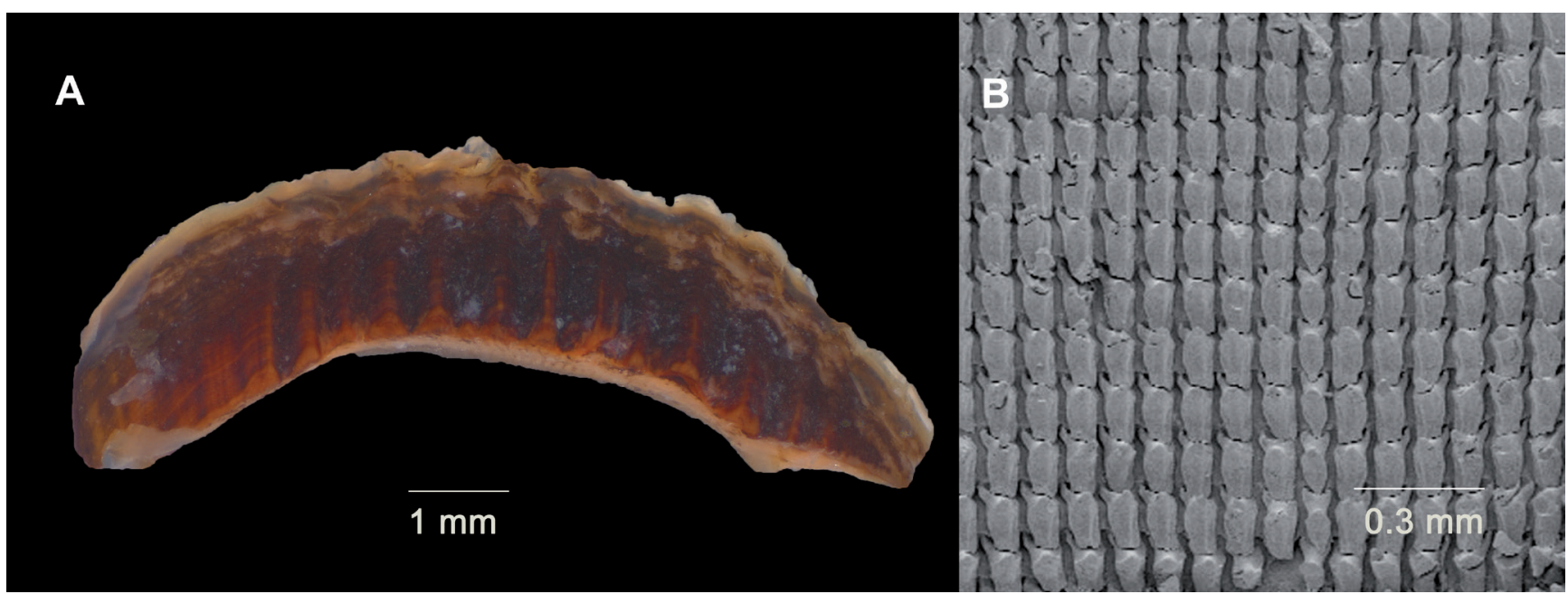

Figure 11. Megalobulimus gummatus anatomy: (A) jaw; (B) radula, central region in SEM.

irregular, round and wide axial columns, and fine transverse growth lines.

Radula (Fig. 11B): With $~ 95$ rows of compressed teeth (47-1-47); lateral teeth rectangular, 1.5 times as long as wide, with single, short, obtuse medially displaced cusp; basal plate limited to corniform lateral extension. Central tooth $20 \%$ smaller, elliptical shape, with apical extensions of basal plate fit anterior tooth.

Genital system: Talon in hermaphroditic duct absent (Figs. 12C, F: hd) directly inserted into base of accessory glandular sac (Fig. 12F: al). Free oviduct appendix absent (Figs. 12C, D-E), free oviduct extremely short (Figs. 12C, D: fo). Penis clavate, with clear separation between base and main body (Figs. 12C: pe, G). Body with strong longitudinal penial folds with anastomoses forming blind background (Fig. 12G: ip), bearing transverse fold near its distal end (Fig. 12G: tf). Epiphallus triangular, narrow and short (Figs. 12C, G: ep), without flagella (Figs. 12C, G), bearing two delicate inner folds (Fig. 12G: el). Penis muscle apical (Figs. 12C, G: mp).

Distribution and habitat: Hidalgo (1870) reported the location of the type specimen as "Province of Rio de Janeiro, occurring among plants where the vegetation is more abundant, being uncommon". The locations of the shells studied by Bequaert (1948) included Cabo Frio (Rio de Janeiro state, RJ), the Corcovado, in the city of Rio de Janeiro, the Mantiqueira Mountain Range near Rio de Janeiro, and 'Gregugi' [sic] River (possibly a misrepresentation of Gongogi River) in Bahia state. Its presence was recorded in archaeological sites in the Camboinhas shellmound, in Niteroi, Rio de Janeiro state, probably transported by humans (Mello \& Coelho, 1989). Judging by the distribution data of M. gummatus specimens from the MZSP collection, its range seems to be currently restricted to the area between Cabo Frio and Arraial do Cabo on the northern coast of Rio de Janeiro state (Fig. 9), in the so-called Região dos Lagos. This region is a semiarid, $1,500 \mathrm{~km}^{2}$ ecological enclave in the humid Atlantic Forest known locally as Caatinga Fluminense. The area is under influence of the oceanic resurgence of the Falkland cold water stream and seasonal winds that dispel clouds and reduce temperature and annual precipitation to about $800 \mathrm{~mm}$. The regional vegetation is considered as a relic of a dry and cold Pleistocene and includes xerophilic Restinga and seasonal forests (Coe \& Carvalho, 2013).

Measurements: Holotype, L: 105 mm; W: 56 mm; S: 5.5 Hidalgo [1872]. Additional shells $(n=21 ; \pm$ standard deviation) L: $111 \pm 4$ mm; W: $69 \pm 4$ mm; H: $53 \pm 2$ mm; S: $5.3 \pm 0.2 ; P: 3.5 \pm 0.1$.

\section{DISCUSSION}

The new species described here was previously understood as a southern population of $M$. gummatus, a species that appears to be restricted to Rio de Janeiro state. Shells of M. dryades sp. nov. were often used in handicrafts, and its capture and transportation for this purpose may be the cause of the apparent range expansion or introduction to relatively distant locations (Fig. 9). The new species is, however, readily distinguishable from the northern species by its peculiar conchological and anatomical characters.

Although the completely white peristome distinguishes $M$. dryades sp. nov. from most Brazilian congeneric species, a more extensive comparison is required to distinguish it from M. chionostoma (Mörch, 1852), M. terrestris (Spix, 1827), M. oosomus (Pilsbry, 1895) and M. valenciennesii (Pfeiffer, 1842), all of which also have a white peristome and occur in eastern Brazil (Simone, 2006). In that regard, M. dryades sp. nov. can be told apart from M. chionostoma (Fig. 13A-F) by the narrower body whorl and shorter but wider aperture, different ground color, and glossy periostracum. Moreover, the shell of M. chionostoma falls within a typical M. ovatus pattern (Bequaert, 1948) consisting of a large, elongated shell (Fig. 13A, D), body whorl surface with chisel-like marks (much more delicate than $M$. dryades sp. nov.), and nepionic shell bearing distal, wide, and incomplete ribs (Fig. 13F). Morretes (1953) reported two records of $M$. chionostoma in Macaé, RJ (Morretes, 1953: figs. 46-48), and Bequaert 
(1948) considered these records reliable. Some of the MZSP specimens examined herein come from Ubatuba, on the northern coast of São Paulo. The taxon M. chionostoma has occasionally been misused to designate M. gummatus, due to the superficiality of Mörch's (1852) original description. According to data from specimens deposited in the MZSP, the range of both species overlap along the coast of Rio de Janeiro.

Remarkably, $M$. dryades sp. nov. resembles $M$. terrestris (Fig. 14A-B), which has a protoconch with spaced complete ribs, a thick but only slightly expanded white peristome, a dorsoventral compression, and a subsutural band (Bequaert, 1948). However, it differs from M. terres- tris by having a much longer shell, and its columella is larger and not arched. In $M$. terrestris, the shell is medium-sized $(\mathrm{L}=77-110 \mathrm{~mm})$ and has a peculiar sculpture on the last whorl (Pilsbry, 1895), which consists of fine microscopic streaks (Rang, 1831) resulting in a hazy periostracum surface. Moreover, $M$. terrestris occurs in the semi-arid Caatinga biome in northeastern Brazil, a very different environment with annual precipitation of about $800 \mathrm{~mm}$, between the states of Bahia, Sergipe, Alagoas, Pernambuco, Paraiba, and Rio Grande do Norte.

Megalobulimus dryades sp. nov. may also resemble M. oosomus (Fig. 14C-F) mainly because of the considerably thickened, expanded peristome, and similar pro-

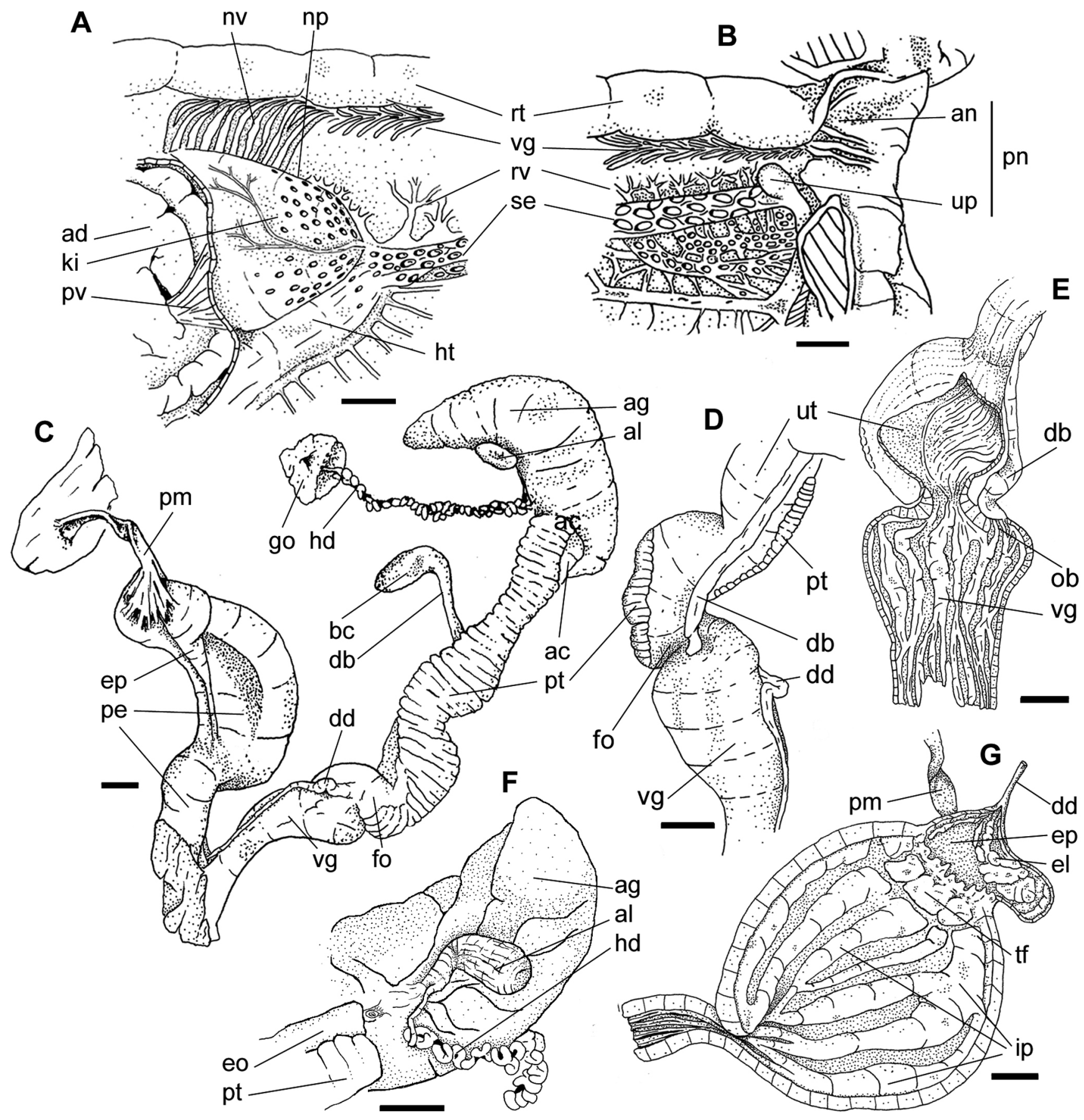

Figure 12. Megalobulimus gummatus anatomy: (A) pallial chamber, renopericardial region, ventral view; (B) pneumostome region, ventral view, inner lip or pneumostome deflected; (C) genital system, complete dorsal view; (D) anterior region of genital ducts, lateral view; (E) same, opened longitudinally; (F) Carrefour region, ventral view; (G) penis and epiphallus opened longitudinally. Scale bars $=5 \mathrm{~mm}$. 
toconch morphology. Nevertheless, M. dryades sp. nov. differs by the larger size, proportionally larger spire, and by the peculiar body whorl surface with fewer delicate marks and lacking minute sparse and irregular granulations (Pilsbry, 1895). M. oosomus was described based on a single shell from Brazil. Bequaert (1948) tentatively used the name for more inflated variations of $M$. terrestris with a very convex body whorl and short, broad spire, blunter apex, and less dorsoventrally compressed shells. Among the specimens diagnosed as M. oosomus by Bequaert, some from the municipalities of Morretes and Antonina in Paraná state (thus being sympatric with $M$. dryades sp. nov.) have a pinkish peristome. We assume that the M. oosomus specimens with a pinkish peristome referred to by Bequaert on the coast of Paraná are variations of M. paranaguensis Pilsbry \& Ihering, 1900. Morretes (1949, 1953), Salgado \& Coelho (2003), and Simone (2006) still reported the occurrence quoted by Pilsbry (1895) but did not add new locations for M. oosomus. Ramírez et al. (2012) recorded its presence in the Brazilian Amazon.

Shells of $M$. dryades sp. nov. are similar to $M$. valenciennesii (Fig. 14G-H) due to their large size (the latter frequently attains $L \sim 125 \mathrm{~mm}$ ), spire with pigmented matrix, the presence of a lighter subsutural band, and white peristome. They differ from $M$. valenciennesii in not having the body whorl densely covered by microscopic, vertical striolae of the periostracum. Its shell also lacks the typical zigzag discolored areas (Fig. 14H) and the flaked peri-

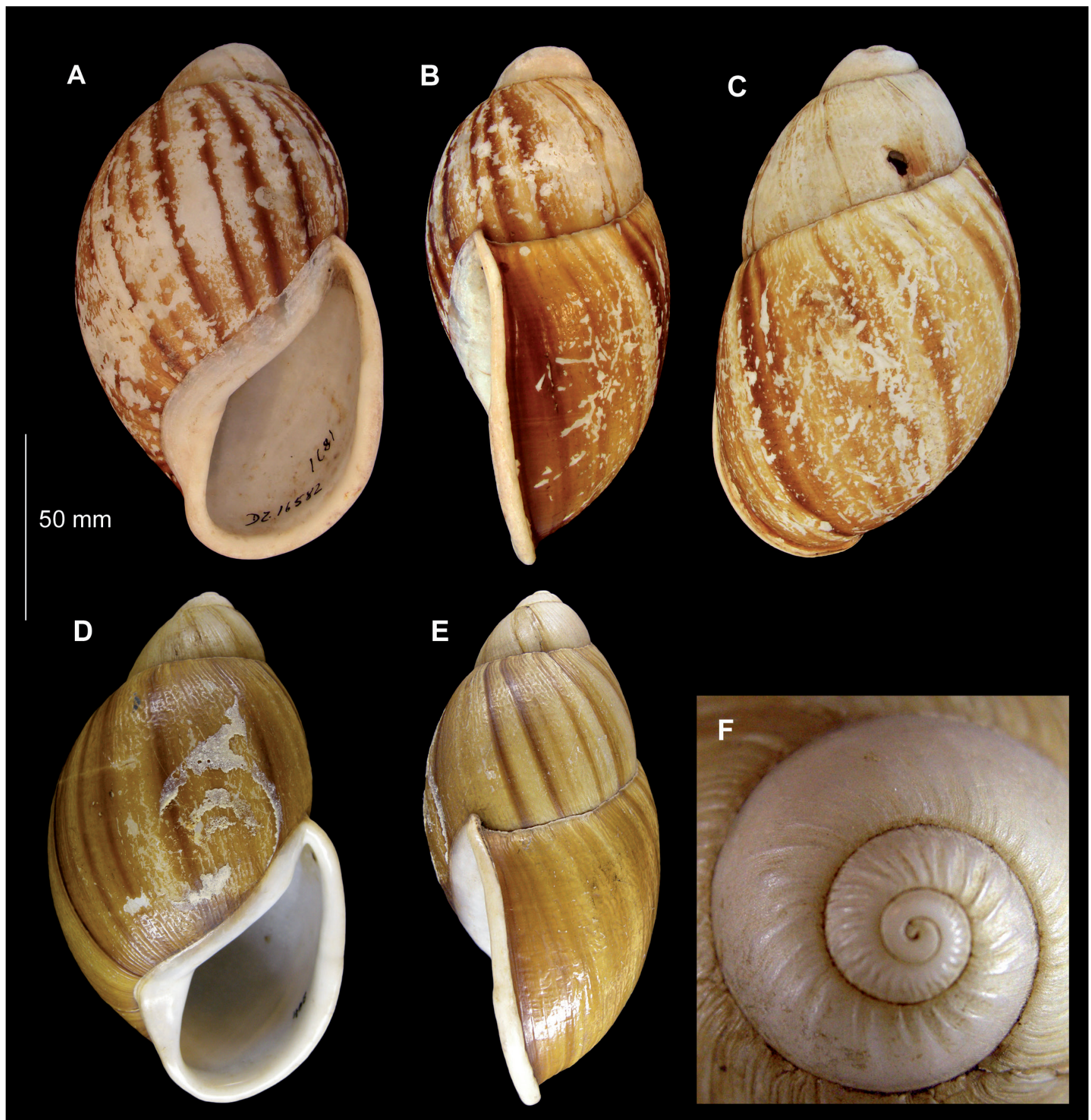

Figure 13. Shells of Megalobulimus chionostoma: (A-C) MZSP 16582 (Corcovado, Rio de Janeiro, RJ, det. Morretes 1953), (A) apertural view, (B) lateral view, (C) abapertural view; (D-F) FMNH 405 (Cantagalo, RJ), (D) apertural view, (E) lateral view, (F) protoconch. 

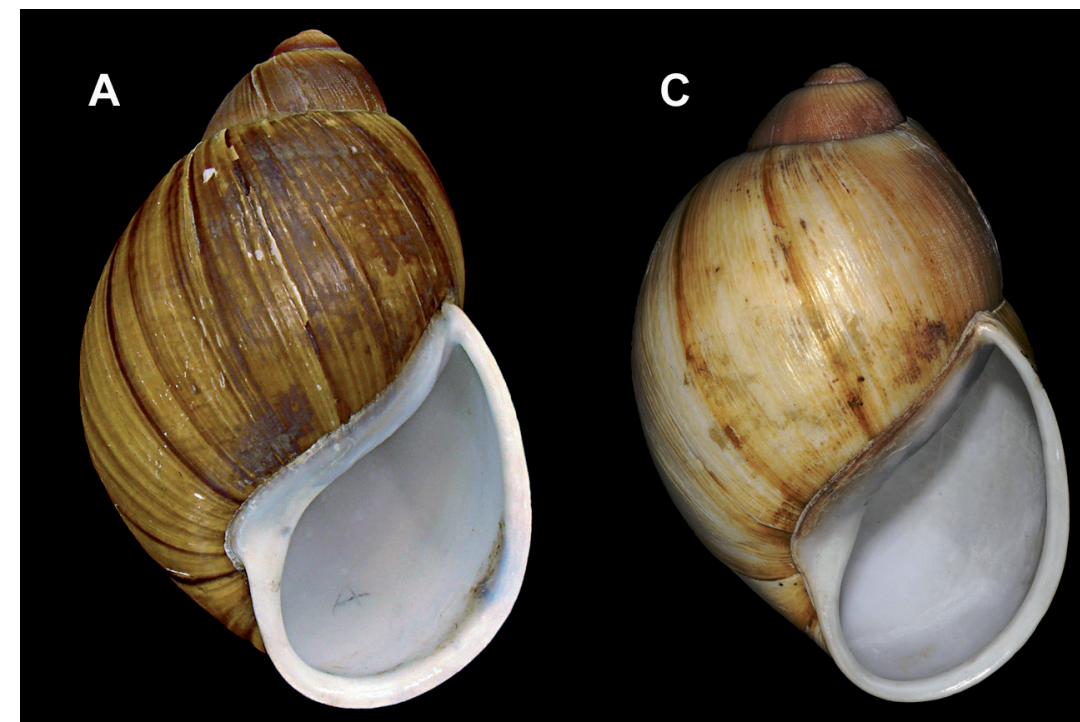

$\mathbf{E}$

B
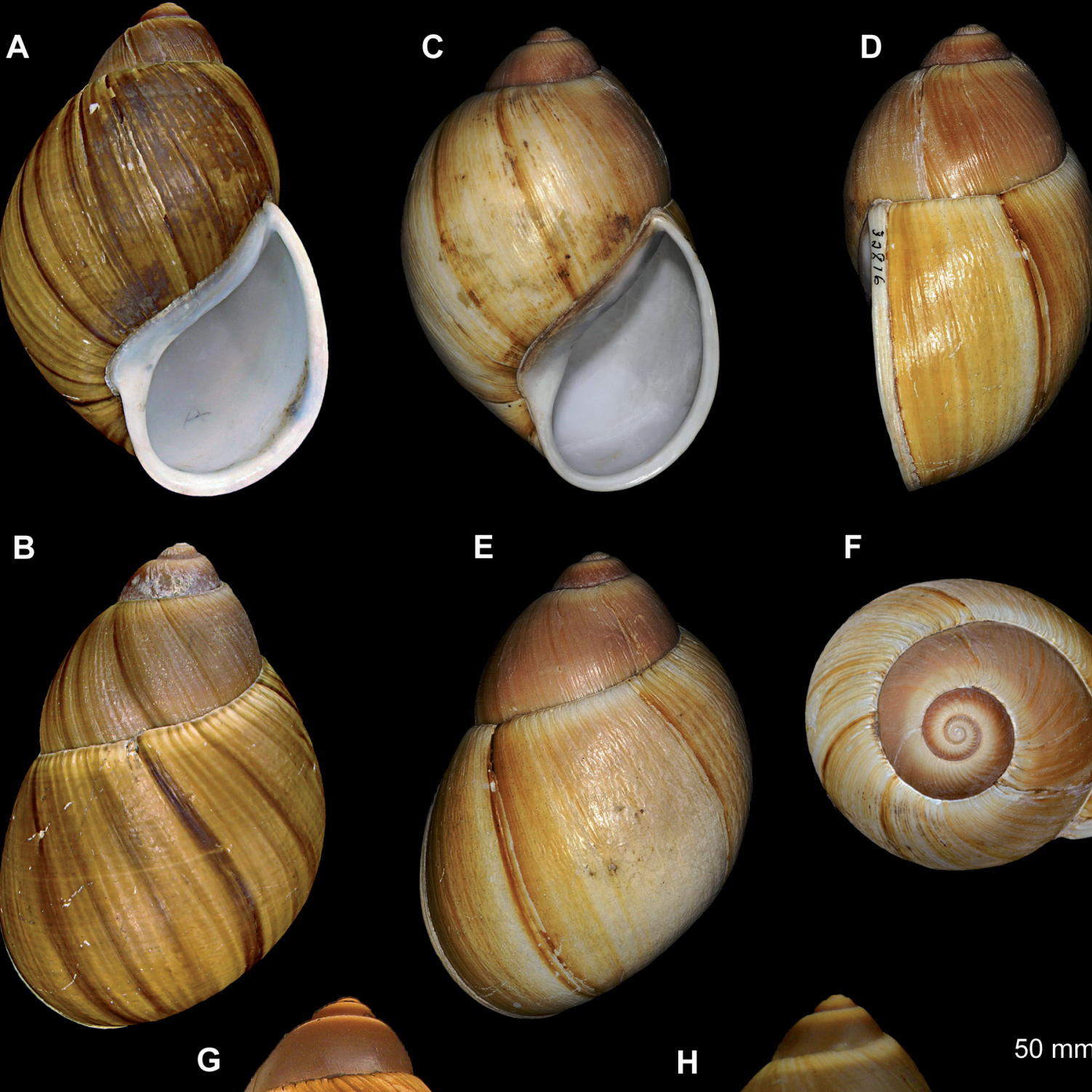

$\mathbf{F}$
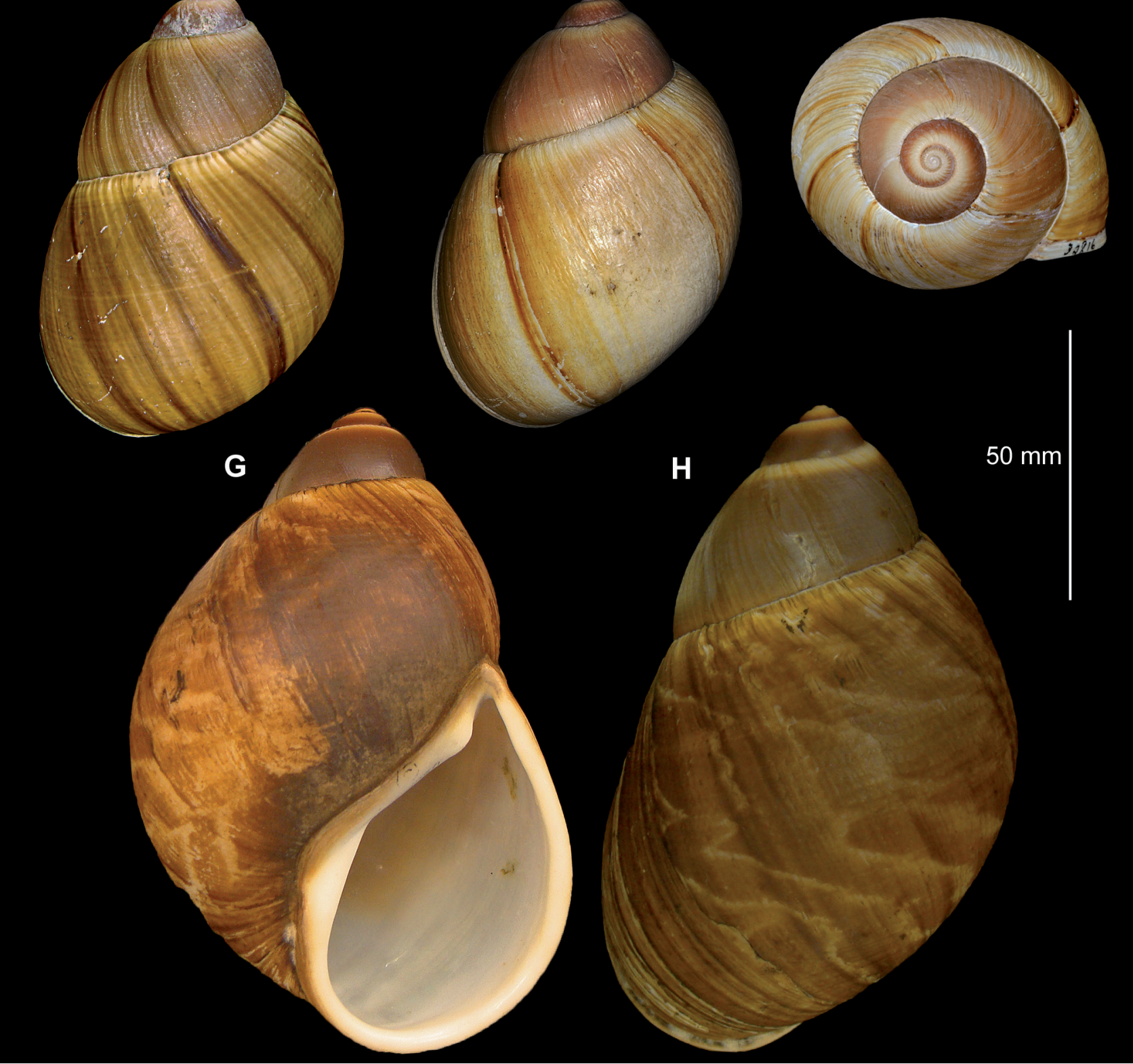

$50 \mathrm{~mm}$

Figure 14. Shells of Megalobulimus terrestris, M. oosomus and M. valenciennesii: (A-B) Megalobulimus terrestris MZSP 29322 (Agostina, PE), (A) apertural view, (B) abapertural view; (C-F) Megalobulimus oosomus, Holotype ANSP 32810 (Brazil), (C) apertural view, (D) lateral view, (E) abapertural view, (F) apical view; (G-H) Megalobulimus valenciennesii MZSP 28940 (Buerarema, BA), (G) apertural view, (H) abapertural view. 
ostracum seen in M. valenciennesii (Bequaert, 1948). The aperture in $M$. dryades sp. nov. is also less dislocated to the left in relation to the columellar axis $(M$. valenciennesii $\mathrm{W} \sim 85 \mathrm{~mm}$ ), and the shell lacks the high and generally open umbilicus and bears an evident callus on the parietal wall. The soft parts of $M$. dryades sp. nov. are lighter and less pigmented, and those of $M$. valenciennesii have strong orange-yellowish pigmentation (M. Uhle, pers. comm.). Both species also have distinct distributions, with $M$. valenciennesii being restricted to the Atlantic Forest remains of southern Bahia state, in northeastern Brazil.

The division of the previous concept of Megalobulimus gummatus into two species, with the "true" M. gummatus occurring in the northern Rio de Janeiro area and M. dryades sp. nov. southward in the São Paulo-Paraná region, has clear implications for conservation efforts. Land snails are widely regarded as some of the most threatened animals on the planet. They are under constant pressure due to anthropic activity and present very high extinction rates (Lydeard et al., 2004; Régnier et al., 2009). Brazilian land snails are not an exception (Salvador, 2019), and the scenario for Megalobulimus species may be even harsher. Despite their large size, they are relatively fragile creatures compared to a local competitor, the very aggressive African invader Lissachatina fulica (Férussac, 1821), which has been reported from the Vale do Ribeira region since 2006 (Eston et al., 2006). While we recognize a species that was once widely distributed as two entities with more limited ranges, we also understand that, in this case, more restricted geographical distributions might mean greater vulnerability. Thus, urgent protective measures must be enforced. The Megalobulimus snails have been considered as umbrella and flagship species for the conservation of the Atlantic Forest biome (Santos, 2011). Though this initiative would certainly increase public awareness of these animals and their environment, we believe that more efforts are still necessary to avoid permanent biodiversity loss. Our results reinforce the urgency to better understand the taxonomy and basic biology of Brazilian Megalobulimus and land snails in general, which is a fundamental step towards effective conservation policies.

\section{ACKNOWLEDGEMENTS}

We thank Rafael Araujo (MNCN), Jochen Gerber (FMNH), Carlo Magenta Cunha, Barbara Tomotani (NIOO), and Francisco Borrero (ANSP), and especially Fernanda Santos Silva (MZSP) for providing images and helpful suggestions. We are also thankful to the anonymous referees for their careful reviews and suggestions.

\section{AUTHORS' CONTRIBUTIONS}

J.H.F.: Conceptualization, data curation, investigation, formal analysis, writing (original draft). L.R.L.S.: Supervision, formal analysis, writing (review \& editing). D.C.C.: Formal analysis, data curation, investigation, writing (review \& editing).

\section{REFERENCES}

Agapow, P.M.; Binnida-Emonds, 0.R.P.; Crandall, K.A.; Gittleman, J.L.; Mace, G.M.; Marshall, J.C. \& Purvis, A. 2004. The Impact of Species Concept on Biodiversity Studies. The Quarterly Review of Biology, 79(2): 161-179.

Agudo-Padrón, A. 2010. The mollusc fauna of Santa Catarina state, Southern Brasil: knowledge gained from 13 years of research. Tentacle, 18: 32-37.

Agudo-Padrón, A. 2011. Threatened freshwater and terrestrial molluscs (Mollusca, Gastropoda et Bivalvia) of Santa Catarina State, Southern Brazil: check list and evaluation of regional threats. Biodiversity Journal, 2(2): 59-66.

Bequaert, J.C. 1948. Monograph of the Strophocheilidae, a neotropical family of terrestrial mollusks. Bulletin of the Museum of Comparative Zoology, 100: 1-210.

Birckolz, C.; Salvador, R.B.; Cavallari, D.C. \& Simone, L.R.L. 2016. Illustrated checklist of newly described (2006-2016) land and freshwater Gastropoda from Brazil. Archiv für Molluskenkunde, 145: 133-150.

Borda, V. \& Ramírez, R. 2016. The genus Megalobulimus (Gastropoda: Strophocheilidae) from Peruvian Andes: Re-description of Megalobulimus leucostoma and description of two new species Re-characterization. American Malacological Bulletin, 34(1): 15-27.

Breure, A.S.H. \& Araujo, R. 2017. The Neotropical land snails (Mollusca, Gastropoda) collected by the 'Comisión Científica del Pacífico'. PeerJ, 5:1-142, e3065. D01.

Coe, H.H.G. \& Carvalho, C.N. 2013. Cabo Frio - Um enclave semiárido no litoral úmido do Estado do Rio de Janeiro: Respostas do clima atual e da vegetação pretérita. GEOUSP, 17(1): 136-152.

Eston, M.R.; Menezes, G.V.; Antunes, A.Z.; Santos, A.S.R. \& Santos, A.M.R. 2006. Espécie invasora em unidade de conservação: Achatina fulica (Bowdich, 1822) no Parque Estadual Carlos Botelho, Sete Barras, SP, Brasil (nota científica). Revista do Instituto Florestal, 18: 173-179.

Fontenelle, J.H.; Cavallari, D.C. \& Simone, L.R.L. 2014. A new species of Megalobulimus (Gastropoda, Strophocheilidae) from Brazilian shell mounds. Strombus, 21(1-2): 30-37.

Hidalgo, J.G. "1869" [1872] Moluscos del Viaje al Pacífico verificado de 1862 a 1865 por una comisión de naturalistas enviada por el Gobierno Español. Parte Primera, Univalvos Terrestres. Madrid, Bailly-Ballière.

Hidalgo, J.G. 1870. Catalogue des coquilles terrestres recueillies par les naturalists de la commission scientifique espagnole sur divers points de I'Amérique méridionale. Journal de Conchyliologie, 18: 27-70.

Leme, J.L.M. 1971. Anatomia e posição sistemática dos Strophocheiloidea neotropicais, coma descrição de uma nova família de Gastropoda Pulmonata. PhD Thesis. São Paulo, Instituto de Biociências da USP. $67 p .+54$ figs. +4 maps.

Leme, J.L.M. 1973. Anatomy and systematics of the neotropical Strophocheiloidea (Gastropoda, Pulmonata) with the description of a new family. Arquivos de Zoologia de São Paulo, 23: 295-337.

Leme, J.L.M. 1989. Megalobulimus lopesi sp. nov., uma nova espécie de Pulmonata terrestre da Mata Atlântica brasileira (Mollusca, Gastropoda, Megalobulimidae). Memórias do Instituto Oswaldo Cruz, 84(Supl.4):313-318.

Leme, J.L.M. 1993. Estudo anatômico sobre Megalobulimus auritus (Sowerby, 1838) (Gastropoda, Megalobulimidae). Papéis Avulsos de Zoologia, 38: 95-105.

Leme, J.L.M. \& Indrusiak, L.F. 1995. Anatomia e considerações sobre 0 Megalobulimus proclivis (Martens, 1888) (Gastropda, Megalobulimidae). Iheringia, Série Zoologia, 78(1): 19-27.

Lydeard, C.; Cowie, R.H.; Ponder, W.F.; Bogan, A.E.; Bouchet, P.; Clark, S.A.; Cummings, K.S.; Frest, T.J.; Gargominy, 0.; Herbert, D.G.; Hershler, R.; Perez, K.E.; Roth, B.; Seddon, M.; Strong, E.E. \& Thompson, F.G. 2004. The global decline of nonmarine Mollusks. BioScience, 54(4): 321-330. 
Mansur, M.C.D. \& Leme, J.L.M. 1996. The endangered giant Megalobulimus from the Atlantic Forest from Brazil. Tentacle, 6(9): 14-15.

Martius, C.F.P. 1840-1869. Tabulae physiognomicae. In: Martius, C.F.P.; Eichler, A.G. \& Urban, I. (Eds.). Flora brasiliensis. Frid. Leipzig, Fleischer. vol. 1, pt. 1, 150p.

Mayr, E. 1977. Populações, espécies e evolução. São Paulo, EDUSP. 485p.

Mello, E.M.B. \& Coelho, A.C.S. 1989. Moluscos encontrados no sambaqui de Camboinhas, Itaipu, Niterói, Estado do Rio de Janeiro, Brasil. Memórias do Instituto Oswaldo Cruz, 84(Supl. 4): 377-380.

Mörch, 0.A.L. 1852. Catalogus conchyliorum quæ reliquit D. Alphonso d'Aguirra \& Gadea Comes de Yoldi. Fasciculus primus. Cephalophora. Hafniae: Klein.

Morretes, F.L. 1949. Ensaio de catálogo dos moluscos do Brasil. Arquivos do Museu Paranaense, 7: 5-216.

Morretes, F.L. 1952. Novas espécies brasileiras de Strophocheilidae. Arquivos de Zoologia de São Paulo, 8: 109-128.

Morretes, F.L. 1953. Adenda e corrigenda ao ensaio de catálogo dos moluscos do Brasil. Arquivos do Museu Paranaense, 10: 37-76.

Pilsbry, H.A. 1895. Tryon's Manual of Conchology, structural and systematic: second series, Pulmonata. Philadelphia, GWTJ. v. 10, 213p.

Rang, M.S. 1831. Description des Coquilles terrestres recueilles pendant un voyage à la côte occidentale d'Afrique, et au Brésil. Annales des Sciences Naturelles, Paris, 24: 5-63.

Ramírez, R.; Borda, V.; Romero, P.; Ramirez, J.; Congrains, C.; Chirinos, J.; Ramírez, P.; Velásquez, L.E. \& Mejía, K. 2012. Biodiversidad y endemismo de los caracoles terrestres Megalobulimus y Systrophia en la Amazonia occidental. Revista Peruana de Biología, 19(1): 59-74.

Régnier, C.; Fontaine, B. \& Bouchet, P. 2009. Not knowing, not recording, not listing: numerous unnoticed mollusk extinctions. Conservation Biology, 23(5): 1214-1221.
Salgado, N.C. \& Coelho, A.C.S. 2003. Moluscos terrestres do Brasil (Gastrópodes operculados ou não exclusive Veronicellide, Milacidae e Limacidae). Revista de Biologia Tropical, 51(Supl. 3): 149-189.

Salvador, R.B. 2019. Land snail diversity in Brazil. Strombus, 25: 10-20.

Santos, S.B. 2011. Land snails as flagship and umbrella species for brasilian Atlantic Forest conservation. Tentacle, 19(2): 19-20.

Simone, L.R.L. 1999. Mollusca Terrestres. In: Brandão, R.F. \& Cancello, E.M. (Eds.). Invertebrados terrestres. São Paulo, FAPESP. p. 3-8. (Biodiversidade do Estado de São Paulo. Volume 5)

Simone, L.R.L. 2006. Land and Freshwater Molluscs of Brazil. São Paulo, EGB/ FAPESP.

Simone, L.R.L. 2018. A new species of Megalobulimus from Potosi, Bolivia (Pulmonata, Strophocheilidae). Strombus, 24(1-2): 1-4.

Simone, L.R.L. \& Leme, J.L.M. 1998. Two new species of Megalobulimidae (Gastropoda, Strophocheiloidea) from north São Paulo, Brazil. Iheringia, Série Zoologia, 85: 189-203.

Sobreira, H.B. \& Molina, F.B. 2002. Observações preliminares sobre a biologia reprodutiva de Megalobulimus gummatus (Mollusca, Megalobulimidae) em laboratório. Arquivos do Instituto Biológico, 69(Supl.): 139-141.

Templado, J.; Baratech, L.; Calvo, M.; Villena, M. \& Apacicio, M.T. 1993. Los "ejemplares tipo" de las colecciones malacologicas del Museo Nacional de Ciencias Naturales. Madrid, Museo Nacional de Ciencias Naturales. 328p. (Monografías del Museo Nacional de Ciencias Naturales, v. 5).

Thomé, J.W.; Arruda, J.0. \& Silva, L.F. 2007. Moluscos terrestres no cone meridional da América do Sul. Ciência e Ambiente, 35(2): 9-38.

Wheeler, Q.D. 2008. Undisciplined thinking: morphology and Hennig's unfinished revolution. Systematic Entomology, 33: 2-7. 